Research review paper

\title{
Towards the design of 3D multiscale instructive tissue engineering constructs: Current approaches and trends
}

\author{
Sara M. Oliveira, Rui L. Reis, João F. Mano*
}

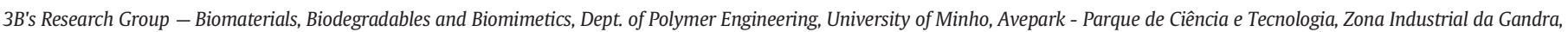
4805-017 Barco- Guimarães, Portugal

ICVS/3B's - PT Government Associate Laboratory, Braga/Guimarães 4805-017 Barco-Guimarães, Portugal

\section{A R T I C L E I N F O}

\section{Article history:}

Received 30 January 2015

Received in revised form 21 May 2015

Accepted 23 May 2015

Available online $\mathrm{xxxx}$

\section{Keywords:}

Scaffolds

Construct

Multiscale

Instructive

Integrative

Bottom-up

Top-down

Building-blocks

Nanobiomaterials

\begin{abstract}
A B S T R A C T
The design of 3D constructs with adequate properties to instruct and guide cells both in vitro and in vivo is one of the major focuses of tissue engineering. Successful tissue regeneration depends on the favorable crosstalk between the supporting structure, the cells and the host tissue so that a balanced matrix production and degradation are achieved. Herein, the major occurring events and players in normal and regenerative tissue are overviewed. These have been inspiring the selection or synthesis of instructive cues to include into the 3D constructs. We further highlight the importance of a multiscale perception of the range of features that can be included on the biomimetic structures. Lastly, we focus on the current and developing tissue-engineering approaches for the preparation of such 3D constructs: top-down, bottom-up and integrative. Bottom-up and integrative approaches present a higher potential for the design of tissue engineering devices with multiscale features and higher biochemical control than top-down strategies, and are the main focus of this review.
\end{abstract}

(c) 2015 Elsevier Inc. All rights reserved.

\section{Contents}

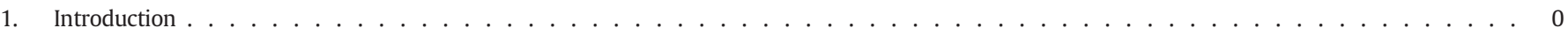

2. Tissue/cell niches as regenerative inspiration for biomaterials design $\ldots \ldots \ldots \ldots$

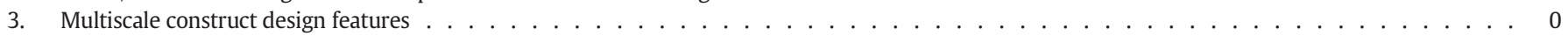

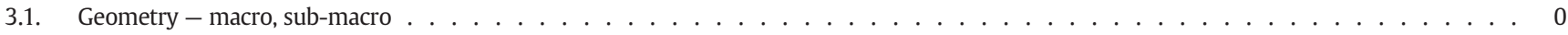

3.2. Cell-anchorage - sub-macro, micro, sub-micro, nano . . . . . . . . . . . . . . . . . . . . . . . . . . 0

3.3. Release systems - micro, sub-micro, nano . . . . . . . . . . . . . . . . . . . . . . . . . . . . 0

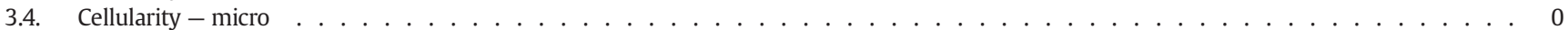

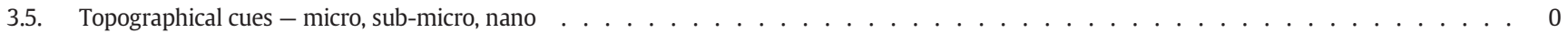

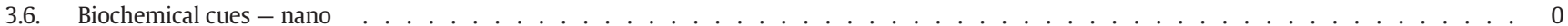

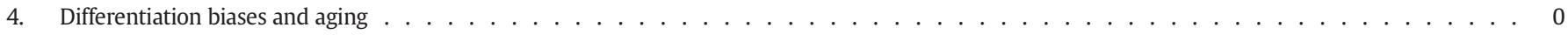

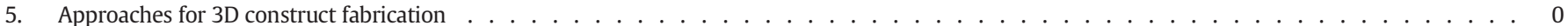

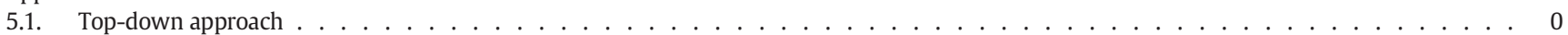

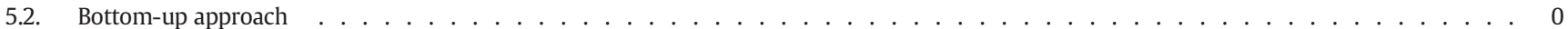

5.2.1. Random assembling . . . . . . . . . . . . . . . . . . . . . . . . . . . . . . . . 0

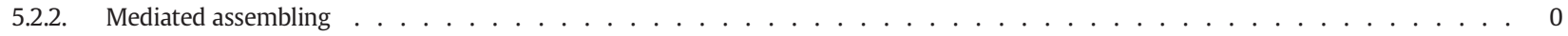

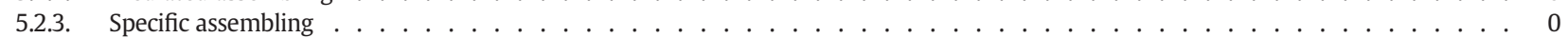

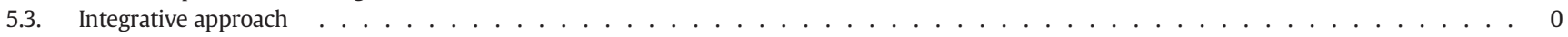

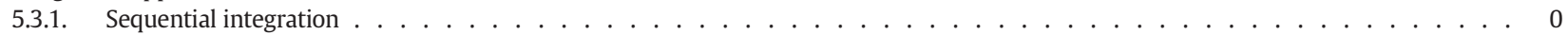

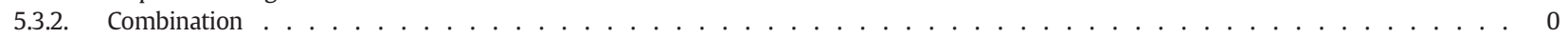

\footnotetext{
* Corresponding author at: ICVS/3B's - PT Government Associate Laboratory, Braga/Guimarães 4805-017 Barco-Guimarães, Portugal.

E-mail address: jmano@dep.uminho.pt (J.F. Mano).
} 


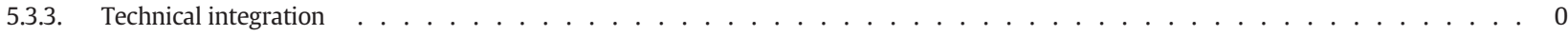

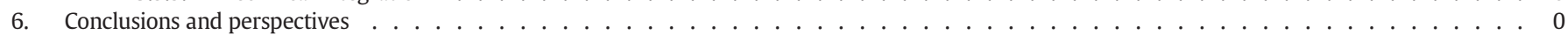

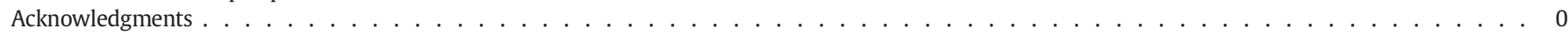

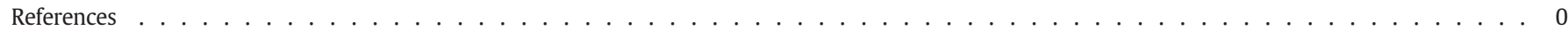

\section{Introduction}

Tissue engineering aims to restore the loss of tissue and organ's functionality resulting from injury, aging or disease (Lanza et al., 2011). Biomaterials, cells and bioactive factors are commonly considered the key elements needed for the preparation of 3D tissue engineered constructs for the regeneration of those damaged tissues (Hench and Polak, 2002; Langer and Vacanti, 1993). Those act primarily as supportive and informative platforms that guide cell behavior. The physicochemical properties of those devices affect cell adhesion, proliferation, differentiation and matrix synthesis. Upon implantation, their properties also dictate host tissue response: inflammatory and immune responses (Franz et al., 2011). Moreover, the cellular and matrix compositions of the injured tissue will influence the cell responses in the construct. The further crosstalk between the construct and the host tissue will thus define the provisional micro/nano-environment, dictating cell behavior and consequently tissue fate: failed healing, repair or regeneration - Fig. 1 (Sephel and Woodward, 2001).

This repairing/regenerative micro/nano-environment is regulated by several cell types, matrix proteins, growth factors and cytokines. Only an adequate balance between new matrix deposition and matrix degradation allows the achievement of a successfully regenerated tissue that is identical to the original one.

Tissue engineering has focused on the design of 3D devices to promote the regeneration of several types of tissues, e.g.: skin (Groeber et al., 2011), cartilage (Mano and Reis, 2007), bone (Healy and Guldberg, 2007), tendon (Hampson et al., 2008), and cardiac tissue (Chiu and Radisic, 2013).

The ideal features of the 3D structures have been evolving with increasing understanding of cell-material interactions both in vitro and in vivo (Custodio et al., 2014a; Hench and Polak, 2002). The intent of the current paradigm of the construct is to provide instructive cues for cellular activation and guidance. Besides demanding an adequate cell instruction regarding migration, proliferation and differentiation, the ideal construct also requires other generic characteristics, such as suitable nutrients and metabolite diffusion, regulated degradation profile and patient-customization. The design of 3D substrates fulfilling all requirements is still very challenging (Mano, 2015; Oliveira and Mano,
2014). It demands the management and understanding of multiple variables that are distributed along all length-scales and affect cell behavior in vitro and in vivo. Processing techniques are still evolving and promise increasing control on the multiscale and spatial-temporal features of the constructs. Herein, we begin summarizing the major occurring events and features in the normal and regenerative cell environment (niche) as design inspirations for instructive biomaterials. We highlight the importance of a multiscale understanding of the range of properties that can be included on the substrates. Lastly, we overview the current and expected tissue engineering approaches for the preparation of $3 \mathrm{D}$ constructs: top-down, bottom-up and integrative approaches.

\section{Tissue/cell niches as regenerative inspiration for biomaterials design}

The stem cell niches are dynamic and complex structures where diverse biochemical, physical, metabolic, inflammatory, and cellularderived cues bi-directionally and reciprocally interact with several local cells and stem cells - Table 1 .

The niches are responsible for modulating stem cell behavior, which is crucial for the maintenance of tissue homeostasis (Jones and Wagers, 2008; Lane et al., 2014; Li and Xie, 2005; Moore and Lemischka, 2006; Schofield, 1977). The ability of the stem cells to self-renew and differentiate is orchestrated by the spatiotemporal presentation of niche's cues and the dialogs occurring with several cell types. Both niches and tissues are multiscale and complex systems where smaller units interact originating larger cellular structures. The secreted factors, the physical cues, the extracellular matrix and other cells interact with the cell surface receptors at the nanoscale creating meso-, micro- and macro-complex structures that are hierarchically and spatially organized (Lane et al., 2014; Nakatsuji, 2013). Among the multitude of surface receptors, cells present super-families of integrins, cadherins, receptor tyrosine kinase, selectins, proteoglycans and immunoglobulins. The type, density and stability of the consequently activated/co-activated receptors trigger specific intracellular events defining cell fate at very different extents, such as: survival, motility, polarity, proliferation, cytoskeleton organization, cell-cell interactions and gene-expression (Bernfield et al., 1992; Borghi et al., 2010; Carey, 1997; Choi et al., 2011; Gumbiner,

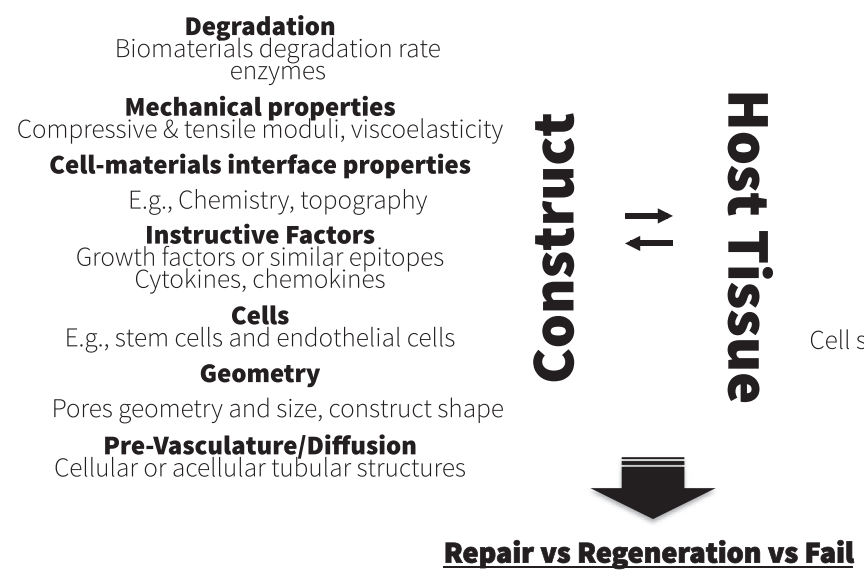

Local enzymes

e.g., metalloprotenases

$\mathrm{pH}, \mathrm{O}_{2}, \mathrm{CO}_{2}$

e.g., acid pH, hypoxia

Instructive factors

Growth factors or similar epitopes

Cytokines, chemokines

Extracellular Matrix

e.g., glycans sulfation, collagen types

Stem Cells, Immune cells, Platelets, etc.

Cell-cell communication

Cell secreted instructive and inflammatory factors, enzymes

Mechanical solicitation

Shear, compression, elongation, torsion

Patient medical conditions

Genetic and metabolic conditions, age

Local vascular network

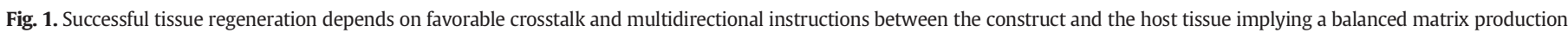
and degradation. 
Table 1

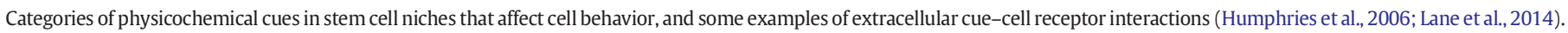
ICAM, intercellular adhesion molecule; VCAM, vascular cell adhesion molecule.

\begin{tabular}{|c|c|c|}
\hline $\begin{array}{l}\text { Cue } \\
\text { category }\end{array}$ & Ligands/cue & Cell receptors/effect \\
\hline \multirow[t]{2}{*}{ Secreted factors } & Chemokine & Chemokine receptors \\
\hline & Growth factors & Tyrosine kinase receptors \\
\hline \multirow[t]{3}{*}{ Extracellular matrix } & Fibronectin & Integrins $\alpha 4 \beta 1, \alpha 4 \beta 7, \alpha \mathrm{V} \beta 3, \alpha \mathrm{V} \beta 6, \alpha \operatorname{IIb} \beta 3, \alpha \nu \beta 1, \alpha 5 \beta 1, \alpha 8 \beta 1$. \\
\hline & Collagen & Integrins $\alpha 10 \beta 1, \alpha 2 \beta 1, \alpha 1 \beta 1, \alpha 11 \beta 1$. \\
\hline & Vitronectin & Integrins $\alpha \nu \beta 5, \alpha \nu \beta 3, \alpha 8 \beta 1, \alpha \operatorname{IIb} \beta 3$ \\
\hline \multirow[t]{2}{*}{ Physical } & Topography & Alters formation of focal adhesion points and cytoskeleton contraction \\
\hline & Stiffness/elasticity & \\
\hline \multirow[t]{4}{*}{ Hypoxia and metabolic } & $\mathrm{O}_{2}$ & Enters cells by diffusion and participates in metabolic process. \\
\hline & $\mathrm{pH}$ & Affects proton transport and the function of cell membrane proteins. \\
\hline & $\mathrm{Ca}^{2+}$ & Calcium channels/pumps; $\mathrm{Ca}^{2+}$ plays important roles in signaling transduction pathways. \\
\hline & Glucose & Glucose transporters; glucose is the main source of energy, among other functions. \\
\hline Cellular & $\begin{array}{l}\text { Tissue specific-cells, stem cells, immune cells, } \\
\text { nerve cells, endothelial cell, stromal cell }\end{array}$ & Cadherins (N, N2, P, E), ICAM, VCAM, integrins (e.g. $\alpha \mathrm{VB3}$ with CD31 in endothelial cell) \\
\hline
\end{tabular}

1996; Hynes, 2002; Kim et al., 2011; Lemmon and Schlessinger, 2010; Takeichi, 1991; Ullrich and Schlessinger, 1990).

The nature of the niche is considerer specific for each stem cell type and tissue (Gattazzo et al., 2014). Nevertheless, the categories of the environmental cues influencing cell behavior are transversal for the tissue, cell or culture type (in vivo, ex vivo or in vitro) - Table 1. Therefore, understanding the normal and regenerative (stem) cell niche and tissue can enlighten and inspire the design of cell instructive biomaterials.

Upon tissue injury, immune cells and others migrate, triggering the healing cascade or an immune response. The healing cascade consists of four major integrated and overlapping phases: hemostasis; inflammation; proliferation and repair; and tissue remodeling or resolution - Fig. 2 (Enoch and Leaper, 2008; Gosain and DiPietro, 2004; Guo and Dipietro, 2010).

The temporary micro/nano-environment of each stage is regulated by several cell types, matrix proteins, growth factors (GFs) and cytokines - Table 2. Extreme changes are known to happen in the physical, biochemical, cell-cell communication and extracellular matrix polysaccharides or protein patterns, during the normal and efficient healing cascade (Witte and Barbul, 1997). The failure, or prolongation, in one phase might result in a delayed or impaired healing. This may be caused by low stem cell availability, aging, continued activation of inflammatory cells, excessive pro-inflammatory MMP, excessive proliferation and matrix synthesis, among others (Forbes and Rosenthal, 2014; Mehta et al., 2012; Menke et al., 2007; Utz et al., 2010; Witte and Barbul, 1997). The repair process may only restore some of the structures of the original tissue and involve scar formation. Only an adequate balance between new matrix deposition and matrix degradation, during the heading, allows a successful regenerated tissue identical to the original one to be achieved.

An injury causes vascular endothelium disruption, exposing the collagen layer and other elements that activate platelets. Nowadays, platelets are recognized as major players in the healing cascade, tissue repair and regeneration (Anitua et al., 2004; Gawaz and Vogel, 2013; Stellos et al., 2010) Besides maintaining the blood vessel integrity by adhering, aggregating and forming a pro-coagulant fibrin surface (hemostasis), platelets initiate the healing process. Once activated, the substances released from the platelet's granules (dense granules, lysosomes and $\alpha$-granules) are responsible for triggering the healing cascade. For instance, $\alpha$-granules contain many instructive GFs, such as: vascular endothelial growth factor (VEGF), fibroblast growth factor (FGF), transforming growth factor $\beta$, (TGF $\beta$ ), epidermal growth factor (EGF), platelet derived growth factor (PDGF) and insulin-like growth factor (IGF). Besides their role in hemostasis, platelets play important anti and pro-inflammatory roles and their releasates also participate in the other healing stages (Gawaz and Vogel, 2013; Semple et al., 2011; Sephel and Woodward, 2001; Vieira-de-Abreu et al., 2012; Weyrich and Zimmerman, 2004; Zarbock et al., 2007). In the early phase, adherent platelets interact with endothelial cells, monocytes and neutrophils. They activate neutrophils and endothelial cells inducing the production of inflammatory cytokines. Platelets are potent instructive cells, and actually have been inspiring and used as a source of multiple instructive a

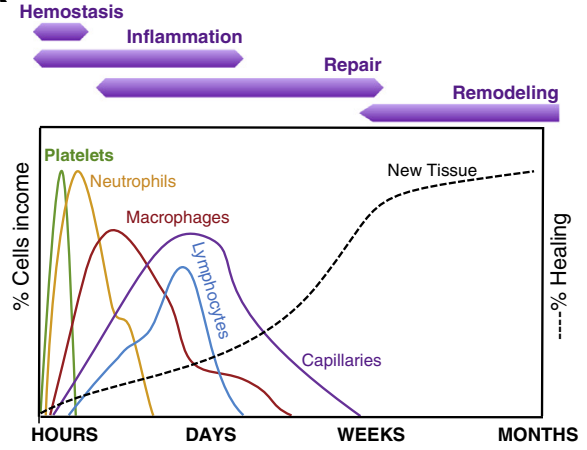

b

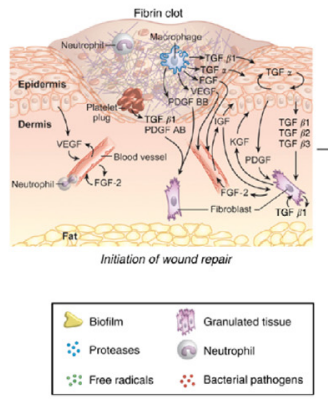

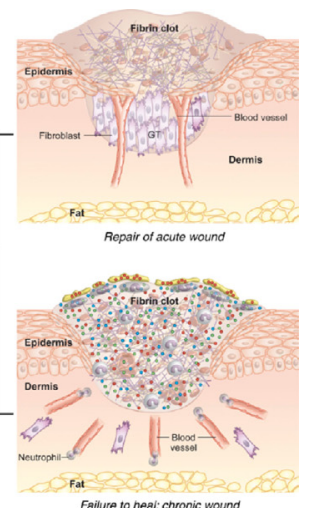

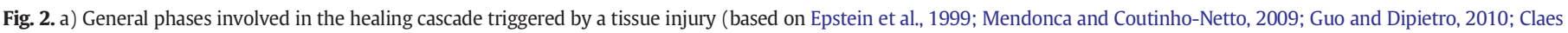

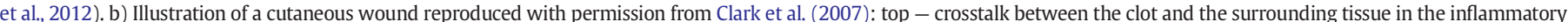

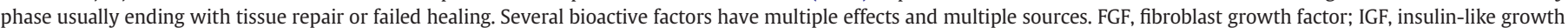

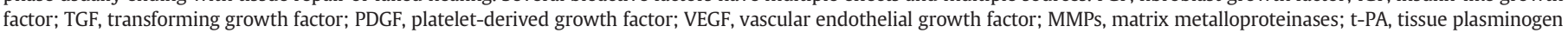
activator; u-PA, urokinase-type plasminogen activator. 
Table 2

Major cell types involved on the healing of injured tissues and their respective function and participating phases.

Adapted from Kamath et al. (2001), Sephel and Woodward (2001), Sipe et al. (2004) and Vieira-de-Abreu et al. (2012).

\begin{tabular}{|c|c|c|}
\hline Cell & Phase & Function \\
\hline Platelets & $\begin{array}{l}\text { Hemostasis } \\
\text { Inflammation } \\
\text { Repair } \\
\text { Remodeling }\end{array}$ & $\begin{array}{l}\text { Major players in hemostasis. Granules release cytokines, chemokines, } \\
\text { GFs, clotting agents, proteases and inflammation mediators. Facilitate adhesion, } \\
\text { coagulation, vasoconstriction, repair and clot resorption. Their activation attracts } \\
\text { and activates several cells }\end{array}$ \\
\hline Leukocytes & Inflammation & $\begin{array}{l}\text { Granulocytes (neutrophils, basophils, eosinophils) and agranulocytes } \\
\text { (lymphocytes monocytes and macrophages) are immune system cells } \\
\text { involved in the foreign-body reaction. The type of leukocytes recruited } \\
\text { is controlled by the type and concentration of the released chemokines in } \\
\text { the injury place. Granulocytes are recruited from bone marrow within the } \\
\text { first day and are responsible for the degradation of unviable tissue releasing } \\
\text { their granule content. For instance, basophils, e.g., release heparin, histamine, } \\
\text { proteases, and chondroitin. Neutrophils can secrete products that stimulate } \\
\text { monocytes and macrophages. }\end{array}$ \\
\hline Mast cells & Hemostasis & Resident cells that contain granules rich in histamine and heparin \\
\hline Resident cells & $\begin{array}{l}\text { Hemostasis } \\
\text { Inflammation } \\
\text { Repair } \\
\text { Remodeling }\end{array}$ & $\begin{array}{l}\text { Tissue resident cells such as resident macrophages and stem cell release healing } \\
\text { mediators in the early and long-term response }\end{array}$ \\
\hline Macrophages & $\begin{array}{l}\text { Inflammation } \\
\text { Repair } \\
\text { Remodeling }\end{array}$ & $\begin{array}{l}\text { Macrophages arrive at the injury site shortly after neutrophils where they } \\
\text { persist for days or longer. Release cytokines, chemokines and GFs. Participate } \\
\text { in the phagocytosis of debris and on the development of granulation tissue }\end{array}$ \\
\hline $\begin{array}{l}\text { Fibroblast, pericytes, } \\
\text { smooth muscles cells }\end{array}$ & $\begin{array}{l}\text { Inflammation } \\
\text { Repair }\end{array}$ & $\begin{array}{l}\text { These cells are recruited by locally released GFs and extracellular matrix } \\
\text { degradation products. In the case of skin, these cells are responsible for matrix synthesis, } \\
\text { wound strength and contraction and tissue remodeling }\end{array}$ \\
\hline Endothelial cells & $\begin{array}{l}\text { Hemostasis } \\
\text { Inflammation } \\
\text { Repair }\end{array}$ & $\begin{array}{l}\text { This cells form capillaries upon GF instruction, which are essential for nutrients, gas, } \\
\text { metabolite diffusion and for the influx of inflammatory cells }\end{array}$ \\
\hline
\end{tabular}

proteins for the preparation of new constructs for several tissueengineering applications (Lima et al., 2015; Oliveira et al., 2015a,b; Santo et al., 2012b). Similar to platelets, other cells involved in the healing cascade play important roles by secreting similar or other instructive compounds such as the leukocytes and other granulocytes - Table 2.
The specific nature of the extracellular matrix of the tissue also regulates the GFs and other bioactive protein distribution, type, and stability (Discher et al., 2009; Kim et al., 2011; Schultz and Wysocki, 2009). GFs are presented either in soluble form, or mainly electrostatically bound to the negatively charged glycosaminoglycans (GAGs). GAGs present various molecular arrangements and different sulfation degrees

Table 3

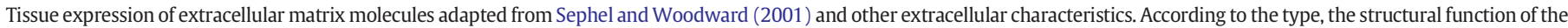
collagen varies: fibrillar collagens (I, II, III, V, XI), network-forming collagen (IV, VIII, X), non-fibrillar collagens (VI, IX, XII, XV, XVIII) and anchoring (VII, XVII).

\begin{tabular}{|c|c|c|c|c|c|}
\hline Tissue or fluid & $\begin{array}{l}\text { Primary } \\
\text { mesoderm cell }\end{array}$ & $\begin{array}{l}\text { Prominent } \\
\text { collagen types }\end{array}$ & $\begin{array}{l}\text { Noncollagen } \\
\text { proteins }\end{array}$ & GAGs and PGs & Others \\
\hline Blood & - & - & $\begin{array}{l}\text { Albumin, fibrinogen, } \\
\text { globulins }\end{array}$ & Hyaluronic acid, sulfated GAGs & $\begin{array}{l}\text { Red and white blood cells, } \\
\text { platelets, plasma }\end{array}$ \\
\hline Dermis & Fibroblast & I, III, V, VI, XII & $\begin{array}{l}\text { Fibronectin, elastin, } \\
\text { fibrillin }\end{array}$ & $\begin{array}{l}\text { Hyaluronic acid, decorin, } \\
\text { biglycan, fibromodulin }\end{array}$ & Stratified and vascularized tissue \\
\hline Muscle & Muscle cell/fibroblasts & I, III, V, VI, VIII, XII & $\begin{array}{l}\text { Fibronectin, elastin, } \\
\text { fibrillin }\end{array}$ & $\begin{array}{l}\text { Aggrecan, biglycan, decorin, } \\
\text { fibromodulin }\end{array}$ & $\begin{array}{l}\text { Soft tissue with oriented actin and } \\
\text { myosin filaments }\end{array}$ \\
\hline Tendon & Fibroblast & I, III, V, VI, XII & $\begin{array}{l}\text { Fibronectin, tenascin } \\
\text { (myotendon junction), } \\
\text { elastin, fibrillin }\end{array}$ & $\begin{array}{l}\text { Decorin, biglycan, fibromodulin, } \\
\text { lumican, versican }\end{array}$ & $\begin{array}{l}\text { Bone-muscle connection. } \\
\text { Mostly collagen } \\
\text { type I forms fiber bundles }\end{array}$ \\
\hline Ligament & Fibroblast & I, III, V, VI & $\begin{array}{l}\text { Fibronectin, elastin, } \\
\text { fibrillin }\end{array}$ & Decorin, biglycan, versican & $\begin{array}{l}\text { Bone-bone connection. } \\
\text { Mostly parallel array of } \\
\text { collagen fibers closely packed }\end{array}$ \\
\hline Cornea & Fibroblast & I, III, V, VI, XII & - & $\begin{array}{l}\text { Lumican, keratocan, } \\
\text { mimecan, biglycan, decorin }\end{array}$ & $\begin{array}{l}\text { Avascular and transparent } \\
\text { stratified tissue }\end{array}$ \\
\hline Cartilage & Chondrocyte & $\begin{array}{l}\text { II, IX, VI, VIII, XI, X } \\
\text { (hypertrophic } \\
\text { chondrocytes) }\end{array}$ & $\begin{array}{l}\text { Anchorin CII, fibronectin, } \\
\text { tenascin }\end{array}$ & $\begin{array}{l}\text { Hyaluronic acid, aggrecan, } \\
\text { biglycan, decorin, fibromodulin, } \\
\text { lumican, perlecan (minor) }\end{array}$ & $\begin{array}{l}\text { Flexible, avascular and ECM } \\
\text { rich in PGs and elastin }\end{array}$ \\
\hline Bone & $\begin{array}{l}\text { Osteocyte, } \\
\text { osteoblasts, } \\
\text { osteoclasts }\end{array}$ & $\mathrm{I}, \mathrm{V}$ & $\begin{array}{l}\text { Osteocalcin, osteopontin, } \\
\text { bone sialoprotein, } \\
\text { osteonectin }\end{array}$ & Decorin, fibromodulin, biglycan & $\begin{array}{l}\text { Rigid and vascularized tissue } \\
\text { containing } 50-70 \% \text { of calcium } \\
\text { phosphate, } 20-40 \% \text { organic } \\
\text { matrix, } 5-10 \% \text { of water and } \\
<3 \% \text { of lipids. Long bones } \\
\text { contain medullar cavity. }\end{array}$ \\
\hline Basement membranes & $\begin{array}{l}\text { Epithelial, endothelial, } \\
\text { adipocytes, Schwann cell, } \\
\text { muscle cells, pericyte, } \\
\text { fibroblasts }\end{array}$ & IV, XV, XVIII & Laminin, nidogen/entactin & $\begin{array}{l}\text { Heparan sulfate, } \\
\text { proteoglycans, perlecan }\end{array}$ & $\begin{array}{l}\text { Nano-stratified membrane } \\
\text { surrounding cells or } \\
\text { cellular structures }\end{array}$ \\
\hline
\end{tabular}


and are usually linked to a small protein core, forming proteoglycans (Kreuger et al., 2006; Nigam and Bush, 2014; Schultz and Wysocki, 2009). Furthermore, the nature of the major cell and protein types forming the extracellular matrix of the tissues shows certain specificity, highlighted in Table 3.

Both the specific nature of the extracellular matrix and the healing cascade have been inspiring the development of cell instructive tissue engineered constructs (Custodio et al., 2014a). Those relevant cues have been incorporated into biomaterials by: i) the incorporation of human or recombinant GFs, or analogues moieties; ii) the incorporation of ECM-tissue specific compounds, or analogues moieties; iii) the use of $\mathrm{co} /$ multi-cultures or cell-cell contact analogues; and iv) the use of immunomodulatory biomaterials. The presentation and incorporation of GFs into biomaterials is commonly controlled by recourse to release systems or surface modification techniques. More translational developments in this area have been hindered by the high cost of recombinant GFs. Thereby, platelet derivatives have attracted immense attention as a human source of multiple GFs and other bioactive molecules demonstrating huge mitogenic, immunomodulatory and differentiation potential (Andia and Maffulli, 2013; Anitua et al., 2004; Cinotti et al., 2013; Kassolis et al., 2000; Kim et al., 2014a; Marx et al., 1998; Oliveira et al., 2015a,b; Semple et al., 2011; Stellos et al., 2010; Vieira-de-Abreu et al., 2012; Weibrich et al., 2002; Weyrich and Zimmerman, 2004).

Engraftment of small peptides mimicking the bioactive epitopes of natural ECM molecules has also shown promising results (Nichol and Khademhosseini, 2009). Frequently, those moieties play important roles during the tissue morphogenesis. For example, the peptide with the sequence of Asp-Gly-Glu-Ala (DGEA), which is derived from collagen type I, has been shown to induce an early-commitment of human mesenchymal stem cells towards the osteogenic lineage (Anderson et al., 2009; Mizuno and Kuboki, 2001). The peptide Glu-Glu-Glu (EEE), which is inspired in the acidic residues of non-collagenous matrix proteins such as osteocalcin and osteopontin, has been shown to promote a more mature osteogenic differentiation than the DGEA (Ceylan et al., 2014).

The combination of different cell types is another approach to obtain a closer representation of the complex cross-talk that occurs in the natural tissue (Battiston et al., 2014). The addition of another cell-type producer of bioactive factors allows a different scheme of interactions, promoting paracrine, autocrine routes and cell-contact dependent effects. Several studies have shown synergistic effects upon the use of co-culture systems and the capability to induce stem cell differentiation (Cooke et al., 2011; J. Wang et al., 2011; Schneider et al., 2011).

Biomaterials for immunomodulation are one of the keys to instruct cell behavior upon implantation and promote the long-term functionality of the device (Forbes and Rosenthal, 2014; Franz et al., 2011; Mokarram and Bellamkonda, 2014). The surgical procedure always initiates an inflammatory response and may elicit an adaptive immune reaction towards the construct surface that should be controlled. Immunomodulatory biomaterials allow the control of the tissue response at the implant site regarding primarily cell adhesion and/or cellular activations. An indirect modulation controls immune cell adhesion and activation, consequently indirectly inducing specific GF secretion. On the other hand, on a direct approach, specific singling molecules are included in the biomaterial (Franz et al., 2011). Controlling hydrophilicity (Jones et al., 2007; Song and Mano, 2013) and fouling properties

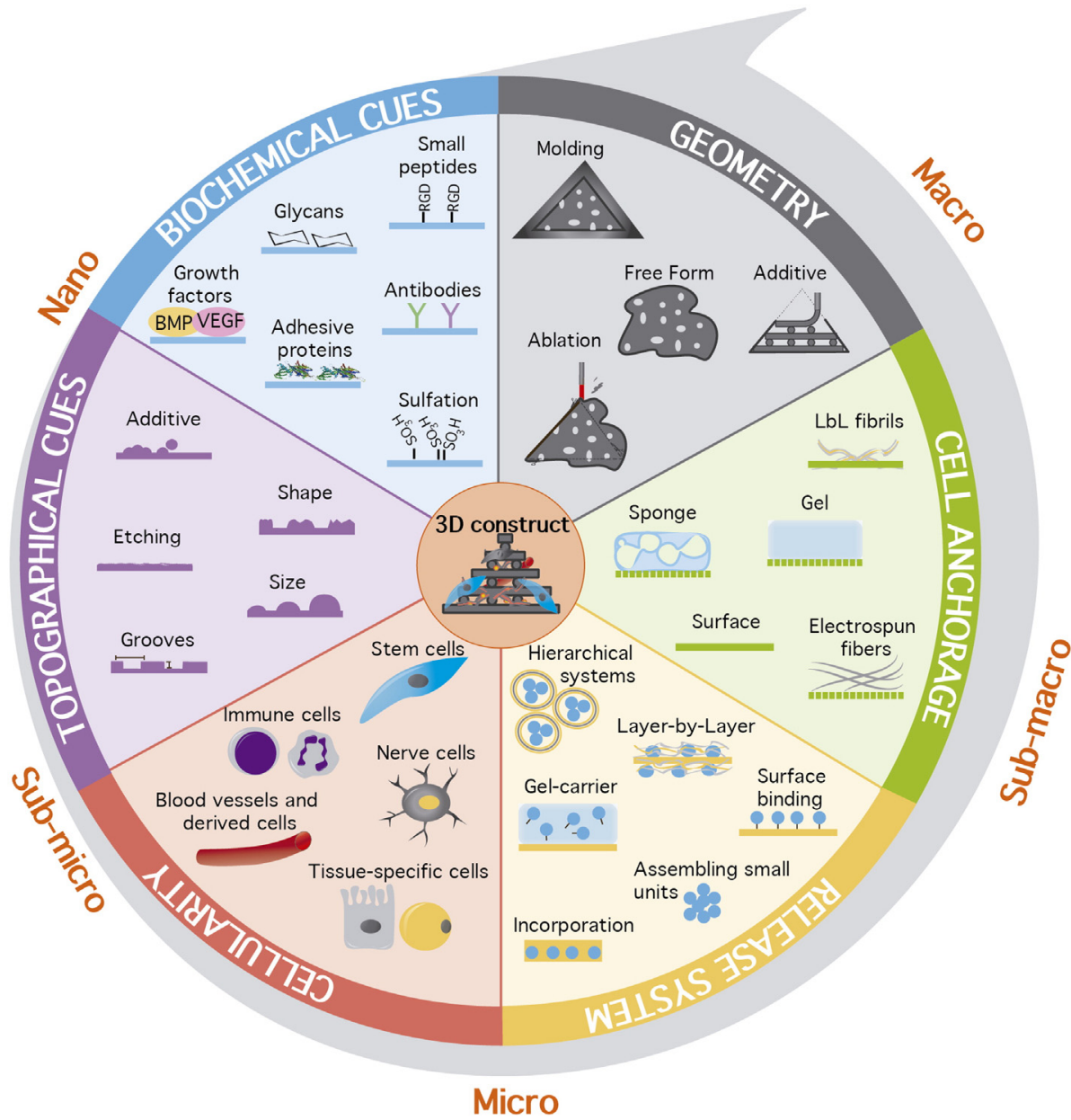

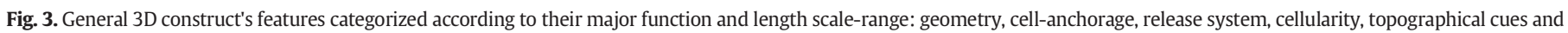
biochemical cues. 
(Zhang et al., 2013), topography/roughness (Fink et al., 2008; Yim and Leong, 2005), adhesion sites (e.g., RGD) (Kao and Lee, 2001; Kao and Liu, 2001), incorporation of anti-inflammatory mediators (Hetrick et al., 2007; Makrydima et al., 2014), self-protein inhibitors (Kim et al., 2014b) and GFs (Caridade et al., 2015; Kehrl et al., 1986; P.M. Chen et al., 2014; Patil et al., 2007), and the use of cells with immunomodulatory properties (Hanson et al., 2014; Singer and Caplan, 2011) are the common applied strategies.

Currently it is technically limitative to fully reconstruct the whole complexity and nature of the healing/regeneration events into a tissue-engineered 3D substrate. Selecting some key events/components of the tissue formation/healing or late-stages may be an efficient approach to drive the formation of tissue constructs. The balanced incorporation of those keys or their bioinspired cues (e.g. epitopes) onto constructs may guide and instruct tissue-specific cell behavior and modulate the healing cascade and immune response.

\section{Multiscale construct design features}

Designing the construct features for in vitro cell fate control and, simultaneous, adequate in vivo performance, is one of the main focuses in tissue engineering (Alves et al., 2010; Lutolf et al., 2009; Marklein and Burdick, 2010). According to the processing approach used for the structure preparation, the best scale working range varies: top-down approaches are more adequate for macro-micro-scale and bottom-up approaches allow higher micro-nano-scale control, while full scale range might be controlled using integrative approaches. Thereby, different approaches offer different control degrees on the final properties of the scaffolds. Nonetheless, multiple variables must be considered, independent of the processing approach. Besides the mechanical properties and the immune reaction, the type and spatial-temporal distribution of the device properties will guide and instruct cell behavior, namely: cell adhesion, cell viability, proliferation, differentiation, matrix production and degradation. According to their major function and scale range, the general scaffold design features can be arbitrarily categorized as: i) geometry; ii) cell-anchorage; iii) release-system; iv) cellularity; v) topographical cues; and vi) biochemical cues - Fig. 3 . The scale definition considered is: macro (>10 mm), sub-macro (100 $\mu \mathrm{m}-10 \mathrm{~mm})$, micro $(1 \mu \mathrm{m}-100 \mu \mathrm{m})$, sub-micro or meso (100 nm-1 $\mu \mathrm{m})$, and nano $(<100 \mathrm{~nm})$.

\subsection{Geometry - macro, sub-macro}

The geometry of the scaffold has, generally, to be tailored according to the implantation site request, in order to fill the tissue's void space and support the site's mechanical demands. Additive (Hutmacher et al., 2004; Melchels et al., 2012; Tsang et al., 2007), ablation (Meng et al., 2009) and molding (C.H. Chen et al., 2014; Correlo et al., 2009; Zhang et al., 2014) technologies, based on previous three dimensional patient data acquisition (e.g., by X-ray microtomography or magnetic resonance imaging), allow the preparation of geometry-specific 3D structures. On the other hand, some applications do not demand specific geometries or high mechanical strength. In such cases, combinations of materials, cells and bioactive factors are usually injected filling the void spaces (Custodio et al., 2015; Custódio et al., 2014; Koshy et al., 2014; Kretlow et al., 2007; Larsson and Hannink, 2011). Shaping the material frequently affects the bulk mechanical properties of the construct. For instance, scaffolds prepared by rapid prototyping show different compression moduli according to the alignment (Hutmacher et al., 2001) or the distance between struts (Sobral et al., 2011). Nonetheless, computer assisted design technologies offer the possibility to simulate and optimize the inner geometry (strut alignment, pore size, pore geometry and interconnectivity) in order to enhance the mechanical performance, by using finite element analysis and CAD design tools (Lacroix et al., 2006; Lin et al., 2004; Sandino et al., 2008). Those micro-features, pore geometry (Bidan et al., 2013; Rumpler et al., 2008), pore size (Oh et al., 2007; Woodfield et al., 2005; Zeltinger et al., 2001) and porosity (Karageorgiou and Kaplan, 2005), also affect oxygen perfusion, the removal of cell metabolites, cell seeding efficiency and tissue growth rate, making them very important features regarding cell viability and growth. Additionally, those micro-properties also influence the invasion of inflammatory and immune cells and the ingrowth of blood vessels or other cells from the host tissue (Karageorgiou and Kaplan, 2005; Karp et al., 2004; Kasten et al., 2008).

\subsection{Cell-anchorage - sub-macro, micro, sub-micro, nano}

The cell-anchorage defines the physical elements supporting the adhesion of the cells at scale smaller than the geometry of the scaffold. Depending on the technique used to shape the materials or, e.g., depending on the subsequent/simultaneous incorporation of gels (Correia et al., 2012; Prabaharan et al., 2007b), sponges (Chen et al., 2003; Mano et al., 2008), micro/nano-fibers or fibrillar structures (S.M. Oliveira et al., 2013b), the anchorage points and the micro-properties of the scaffold can be tailored. Introducing anchorage points within the pores is also a way to increase cell surface growth area/volume and alter the spatial distribution of the tissue growth. Moreover, their physical properties (e.g. stiffness/elasticity and adhesion area) will affect cell morphology by altering the cytoskeletal organization and contractibility, which can guide stem cell differentiation into specific lineages (Engler et al., 2006; Guilak et al., 2009).

\subsection{Release systems - micro, sub-micro, nano}

The incorporation of release systems in the substrates is considered an essential tool for the temporal or spatial-temporal controlled delivery of instructive or pharmaceutical compounds (Lima et al., 2012; Madduri and Gander, 2012; Oliveira and Mano, 2011; Santo et al., 2012c, 2013). Some examples of release systems of interest in tissue engineering relate to the delivery of one or multiple compounds such as GFs (Johnson and Wang, 2013; Kim et al., 2013; Richardson et al., 2001; Tabata, 2003), dexamethasone (Duarte et al., 2009a; Wang et al., 2010, 2014), gentamicin (Gao et al., 2011; Li and Chang, 2005), ketoprofen (Prabaharan and Mano, 2005; Prabaharan et al., 2007a) and platelet derivatives (Coppinger et al., 2004; Kawase et al., 2003; Santo et al., 2012a; Y.K. Kim et al., 2014). Typically, a release-system can be prepared by the sole mixing of the compounds with the materials prior to the 3D processing (Perets et al., 2003; Santo et al., 2012a), or by its incorporation afterwards, using surface modification techniques (e.g., by layer-by-layer assembling (Gilde et al., 2012) or adsorption (Santo et al., 2012b)) or impregnation (e.g. supercritical fluid $\mathrm{CO}_{2}$ (Cabezas et al., 2014; Biondi et al., 2008)). In combination with stimuli responsive materials (Mano, 2008), these systems can be triggered in a controlled manner, for instance by temperature (Costa et al., 2009; Shi et al., 2008), pH (Costa et al., 2009; Santos et al., 2010) and light stimuli (Borges et al., 2014; Mano, 2008; Stuart et al., 2010). Besides being interesting for the development of smart release systems, stimuli responsive materials have been shown to provide variations in other important properties, such as wettability, affecting cell adhesion (da Silva et al., 2007) or mineralization (Cole et al., 2009; Shi et al., 2007).

\subsection{Cellularity - micro}

For cellular tissue engineered approaches, the type of cells seeded on the 3D structure has major percussions on new tissue formation. According to the source tissue or donor, stem cells possess different differentiation potentials (Bianco et al., 2001; Chamberlain et al., 2007; Kern et al., 2006; Odorico et al., 2001). Moreover, the seeding of more than one cell type (i.e. co/multiple cell culture) and the ratio between those cells allows different crosstalk to occur. The presence of other cells will affect the nano/micro-environment, e.g., by creating a new profile of cell-secreted cytokines and GFs (Cooke et al., 2011; Schneider et al., 
2011; Wang et al., 2011a). Additionally, variables such as cellular density can affect cell growth (Dar et al., 2002; Rodriguez et al., 2001; Wentao et al., 2006) and differentiation (Bitar et al., 2008; Lee and Hu, 2013; Masur et al., 1996; Poumay and Pittelkow, 1995).

\subsection{Topographical cues - micro, sub-micro, nano}

The nano/micro-topographical cues are one of the primary mediators of the adsorption of proteins, from the surrounding media (e.g., serum media or plasma), that further mediate the cell adhesion process (Lord et al., 2010; Raffaini and Ganazzoli, 2013; Roach et al., 2006; S.M. Oliveira et al., 2014; Song and Mano, 2013). Controlling these features can synergistically improve cell behavior. As it has been shown, designing specific surface grooves and patterns can induce specific cell shapes (Chou et al., 1995; McBeath et al., 2004; Singhvi et al., 1994) or alignments (Hosseini et al., 2014; Lucker et al., 2014; McCloskey, 2013) that alter cytoskeleton contractibility guiding cell differentiation. Wellcontrolled topographical cues, patterns and surface biochemistries can be easily prepared in 2D. However, the transposition of those features to 3D is still a major challenge. Surface properties design and surface engineering techniques have been extensively reviewed elsewhere (Alves et al., 2010; Brafman, 2013; Costa and Mano, 2014; Discher et al., 2009; Dvir et al., 2011; Han et al., 2014; Lutolf and Hubbell, 2005; Lutolf et al., 2009; Marklein and Burdick, 2010).

\subsection{Biochemical cues - nano}

At the nanoscale, the surface biochemistry instructs cell behavior either by directly mediating the adsorption of surrounding proteins to the construct, or by binding/activating cell surface receptors - Table 1 . The biochemical cues, such as GFs (Gitay-Goren et al., 1992; King and Krebsbach, 2012; Saik et al., 2011), extracellular matrix proteins (Custodio et al., 2010; Sayyar et al., 2014; van den Dolder et al., 2003; Zhang et al., 2005) (e.g., collagen and fibronectin), functional groups (Amorim et al., 2013; Arima and Iwata, 2007; da Costa et al., 2012) (e.g. sulfation (S.M. Oliveira et al., 2013a)), small peptides (Hersel et al., 2003; Massia and Hubbell, 1990, 1991) (e.g., -RGD), and cell contacts (Chen et al., 2004; Lambert et al., 2000) (e.g., cell-cell interactions or functional groups mimicking cells contact) will trigger specific singling pathways in the cell and define their fate. A controlled design of the biochemistry is commonly made recurring to nanotechnologies and surface modification methods, such as: layer-by-layer assembling (Jan and Kotov, 2007; Macdonald et al., 2011; Martins et al., 2010; Neto et al., 2014; S.M. Oliveira et al., 2013a) and antibody mediated binding (Custodio et al., 2014b; Custódio et al., 2014).

Despite most features might be roughly allocated to a defined range of length scale, their properties can be intimately related with other features (S.M. Oliveira et al., 2014). A classical example is the case of roughness-wettability (Neto et al., 2011; S.M. Oliveira et al., 2011, 2014). Introducing nano/micro-roughness in a substrate in the first instance may represent a higher surface area available for cell growth. Nevertheless, the altered roughness might also change the surface wettability into values that are not as favorable for cell adhesion/growth (Alves et al., 2009; Song et al., 2009). Whether the ability of a surface to be wet is altered, its profile of protein adsorption will also change in terms of conformation and density of proteins. Consequently, the communication between cell and the support can be significantly altered at the cell receptor level (Gittens et al., 2014).

\section{Differentiation biases and aging}

Regenerative success is intricately dependent on all the interactions that cells are subjected to upon the in vitro culture, the interaction with the construct and the in vivo implantation. Besides the crucial roles of the biomaterials' properties considered in most of the research conducted in tissue engineering explored in the last section, there are others affecting mostly the cellular phenotype and genotype quality. Those features concern issues such as cell senescence, aging and differentiation biases.

Most of the commonly used in vitro expansion platforms are not adequate and damage cell telomeres, causing cell senescence, aging, reduction of differentiation potential and differentiation biases (Haik et al., 2000; Oh et al., 2014; Salehinejad et al., 2013). The conditions used for stem cell expansion can alter the lineage fate. Moreover, it has been reported that stem cells have mechanical memory of previous culture conditions (Yang et al., 2014). Also, it has been shown that the chemistry of the surface used to expand stem cells does affect their in vivo regeneration capability (Huang et al., 2014), as well as the tendency for a certain lineage differentiation (Hsu and Huang, 2013). For instance, the biases lineagecommitment tendency of mesenchymal stem cells to undergo aging, telomere shortening, and spontaneous low quality osteogenic differentiation upon regular culture expansion, as well as decreased multilineage differentiation quality has been reported ( $\mathrm{Li}$ et al., 2011; Yang et al., 2014). To overcome those issues, geometrical, topographical and physical cues can be used to alter cytoskeleton contractibility, guiding stem cell lineage specification, and reducing the biases as well as telomerase activator can be incorporated in order to delay telomeres shortening (Engler et al., 2006; Guilak et al., 2009; Kilian et al., 2010; Reilly and Engler, 2010). There is still an urgent need to develop and spread anti-aging, anti-biases procedures, and new 2D/3D expansion substrates to improve specificity, cellular performance and tissue regeneration.

\section{Approaches for 3D construct fabrication}

3D constructs can be prepared using top-down, bottom-up or integrative methodologies. Those approaches allow varied length scale degrees of control of the building and final properties. Using topdown approaches, well-defined scaffolds, where multiscale control is not a demand, can be prepared, whereas bottom-up stands for a higher control at the nano/micro scale. On the other hand, integrative approaches emerge as a combination of both top-down and bottom-up approaches, promising scaffolds with properties and features controlled over the entire scale range. Bottom-up and integrative approaches present higher potential for the design of supportive biomaterials with multiscale features and high biochemistry control than top-down, being more focused in this review.

\subsection{Top-down approach}

Top-down approaches provide considerable higher control over the macro/micro scale properties/features rather than the nano/sub-micro ones. A bulk material is scaled down into small compartments or nanoscale details are incorporated, indirectly controlling the processing parameters of the fabrication technique (Yan et al., 2011). Top-down scaffolds have been produced recurring to several processing techniques, such as: freeze-drying (Correia et al., 2011; Ho et al., 2004; Wu et al., 2010), solvent-casting (Mota et al., 2012; S.S. Silva et al., 2013; Sin et al., 2010; Thadavirul et al., 2014), electrospinning (Park et al., 2008; Yoshimoto et al., 2003; Zong et al., 2005), rapid prototyping (Landers et al., 2002; Silva et al., 2009; Yang et al., 2002) and supercritical fluids (Duarte et al., 2009b, 2012). They present pores and mechanical properties that can be controlled to some extent, for instance, by controlling the inner architecture and the nature of the materials. In particular, rapid prototyping allows a precise and computer assisted design of the inner geometry and, simultaneous, control of the external shape. All different kinds of materials and blends, including natural and synthetic polymers and proteins, ceramics and metals, have been used to prepare 3D constructs. With exception of extracellular derived compounds or moieties that not always are obtained from cost- 


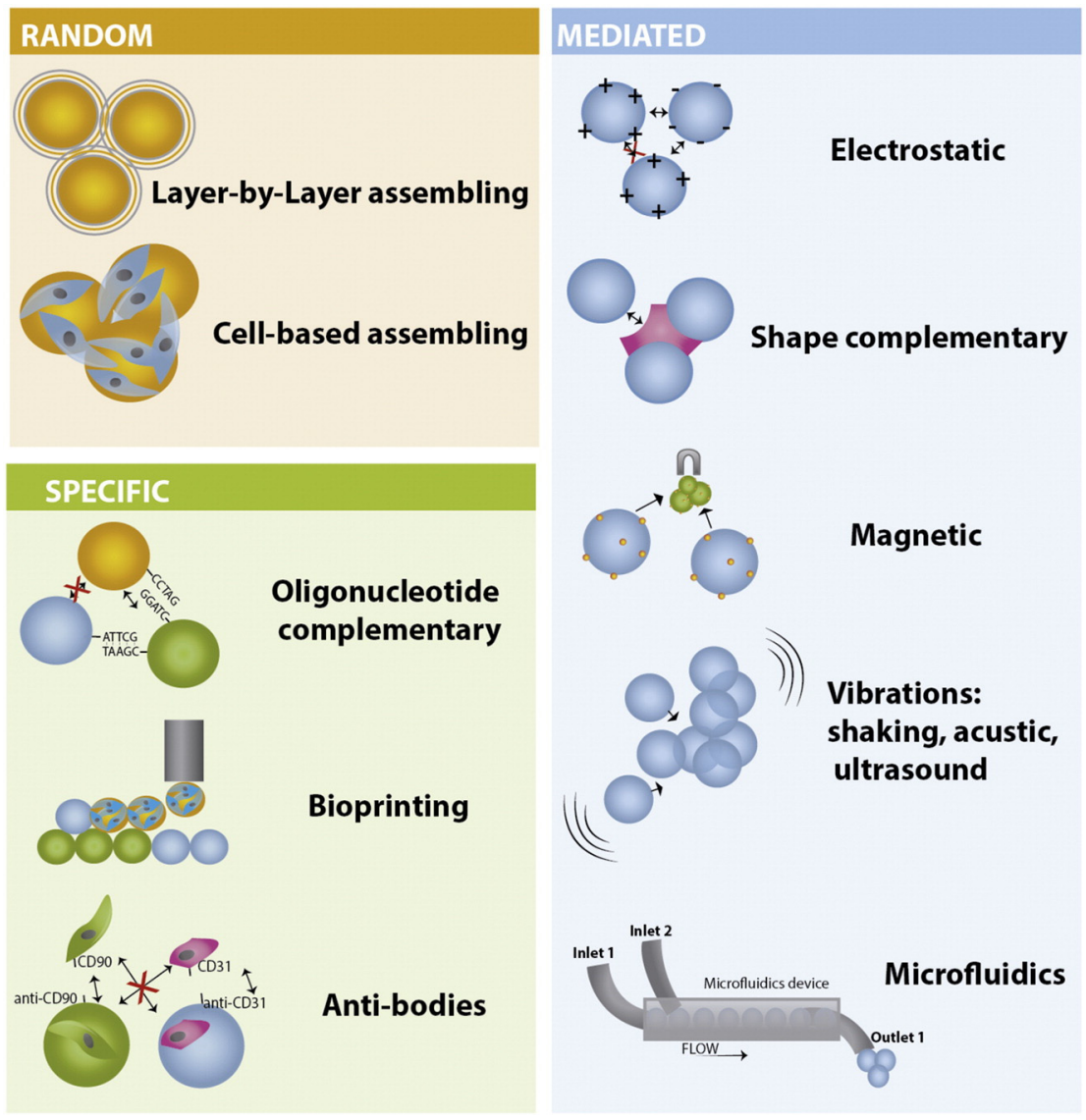

Fig. 4. Current strategies employed for the bottom-up assembling of small units: random, mediated and specific.

effective sources, those constructs frequently lack cell instructive cues (Silva et al., 2010). To improve cell behavior on such structures, usually the scaffolds are prepared combining different top-down techniques (W. Wang et al., 2011; Yeo and Kim, 2014) or are subjected to further functionalization requiring integrative approaches (Macdonald et al., 2011; S.M. Oliveira et al., 2013b; Yeo and Kim, 2011). For instance, electrospinning and 3D printing can be combined to prepare hierarchical scaffolds with dual scale fibers: the printed micro-struts combined with electrospun nano/microfibers (Park et al., 2008; Santos et al., 2008; Tuzlakoglu et al., 2005). The electrospun fibers increase cellanchorage points and seeding efficiency (Park et al., 2008) and can promote cell alignment (Park et al., 2014).

\subsection{Bottom-up approach}

Bottom-up methodologies are those applying chemical or physical forces leading to the assembling of micro/nanoscopic-defined building blocks into larger scale structures. The chance to control the construct over several length-scales makes this approach more attractive for matrices' engineering than the top-down approach, namely in finding new opportunities to mimic a tissue microstructure and the spatial organization of multiple cell types (Nichol and Khademhosseini, 2009). The most commonly used building blocks comprise cells, cell aggregates/spheroids, nano/microparticles, tubes, layers, fibers and gels. The development of methodologies to produce, functionalize, and assemble those small units is the major challenge - Fig. 4. Currently, there are three general alternatives to assemble the units: i) randomly; ii) mediated by an external force; and iii) specifically assembled - see Fig. 4.

\subsubsection{Random assembling}

Layer-by-layer assembling ( $\mathrm{LbL}$ ) is a simple and random bottom-up assembling method based on the alternated deposition of polyelectrolytes with different charges (Borges and Mano, 2014; S.M. Oliveira et al., 2013a; Tang et al., 2006). Using LbL, multilayered structures can be created around the units, binding and stabilizing the entire set and forming a scaffold (Miranda et al., 2011; Sher et al., 2015a,b), temporary templates to produce high porous foams (J.M. Silva et al., 2013; Sher et al., 2010) or hierarchical capsules (Correia et al., 2013; Costa et al., 2013). Such extension of the LbL methodology towards the fabrication of 3D structures is an example of the application of this technology in the biomedical field (Costa and Mano, 2014).

It has also been shown that the building blocks can be unspecifically assembled by cells which colonize their surfaces, consolidating the structure (García Cruz et al., 2008; M. B. Oliveira et al., 2011; McGuigan and Sefton, 2006). The presentation of cell-recognizable moieties on the surface can accelerate this cell-based assembling. For instance, chitosan microparticles functionalized with a mitogenic GF (PDGF) have shown a stable and faster assembling, within $12 \mathrm{~h}$, than in the absence of PDGF (Custódio et al., 2014).

Scaffold free technologies represent another derivation of the bottom-up approach. Cells grown on thermoresponsive culture dishes are retrieved as a confluent monolayer, containing the extracellular matrix proteins, by decreasing the local temperature (da Silva et al., 2007; Yang et al., 2005, 2007). These cell sheets can be consecutively stacked on top of each other to produce thicker and more complex tissues. A reported alternative is based on consecutive cell seeding on top of confluent cell layers previously coated with proteins (Chetprayoon et al., 2013; Matsusaki, 2012). The preparation of thick cell-constructs and their low load-bearing capability are the major challenges in using such technology in tissue engineering.

\subsubsection{Mediated assembling}

The assembling of small units can be guided by external stimuli, allowing the control over their spatial organization to a certain extent. 

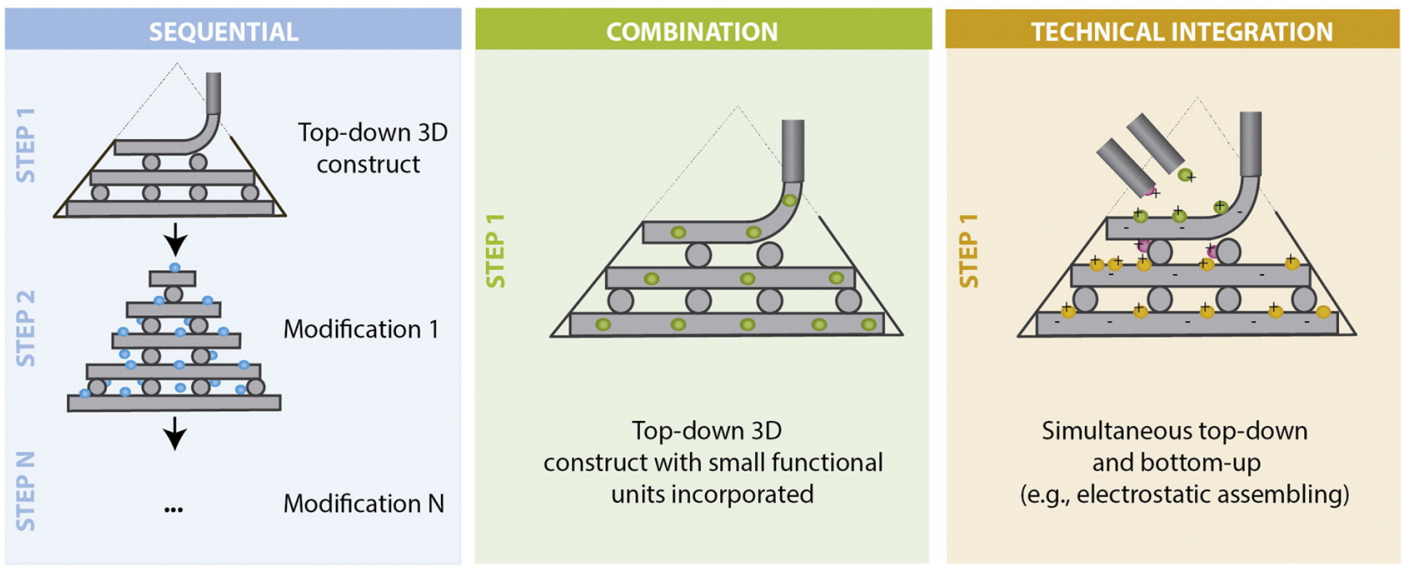

Fig. 5. Different integrative approaches for the preparation of 3D constructs: sequential, integration by combination and technical integration.

For example, the successful attachment of gel surfaces has been demonstrated using silica particles (Abe et al., 2014a,b; Tamagawa and Takahashi, 2008). Through electrostatic interactions at the particle-gel interface and cohesion forces in the particle layer, two gel-surfaces can be attached. The adhesion force, mediated by the particles, can reach $20 \mathrm{kPa}$ as opposed to $1.5 \mathrm{kPa}$ when using an oppositely charged polyelectrolyte solution (Abe et al., 2014a,b; Tamagawa and Takahashi, 2008). Hydrogel units composed of materials presenting opposite charges can also be assembled by electrostatic attractions (Katayama et al., 2013). However, to promote the electrostatic binding, the distance among the units has to be decreased, e.g. by direct positioning (Abe et al., 2014b), by shaking (Katayama et al., 2013) or using acoustic waves (Xu et al., 2011a). Alternatively, it has been shown that template gels can be successively dipped onto oppositely charged micro-gel colloid to form multilayered-like constructs (Han et al., 2013). Moreover, the use of shape complementary building blocks allows the formation of lock-and-key shaped assemblies mediated by electrostatic interaction or surface tension (Du et al., 2008; Katayama et al., 2013). In alternative, magnetic nanoparticles can be incorporated into cells (Castro and Mano, 2013; Souza et al., 2010) and biomaterial units (Gil and Mano, 2014; Liu et al., 2014; Xu et al., 2011b) and further 3D organized recurring to an external magnetic field. However, until now a perfect control of the position in the space of the different unit has been limited.

\subsubsection{Specific assembling}

While the alternatives for the unspecific 3D assembling of building block are many, the current available methods to design 3D constructs with specific spatial organizations are yet limited and more complex.

Microfluidic technologies have been proposing promising tools for the assembly, for example, of small gel units mostly by mediated assembling. By controlling the inlets, outlets and flow, some microfluidic devices can actually guide the assembling of small units into 1D, 2D and 3D structures (Chung et al., 2011). Moreover, it has been shown that using the so-called multilayer-microfluidic devices, mosaic hydrogels with a well-defined spatial composition of materials, cells or pores can be prepared (Leng et al., 2012).

Based on the oligonucleotide pairs complementarity principle, gel interfaces can be specifically assembled (Deschner et al., 2014; Qi et al., 2013). Setting the spatial/surface presentation of the complementary sequences in the different units allows the formation of controlled assemblies. Although being assemble-specific, this approach might be scale-up limitative. Other alternative methods, for both materials and cell controlled assembling, are based on bioprinting technologies. Bioprinting is a particular type of rapid prototyping technique that deposits small units of multiple materials and cells, instead of continuous filaments (Schuurman et al., 2011). Highly complex organization with cellular vascular networks, multiple cell types and extracellular matrices were already shown to be achievable (Kolesky et al., 2014).

Even though bottom-up approaches seem ideal to mimic a tissue organization, major developments and new concepts to improve the assembling and spatial organization of the assembling units still necessary. Limitations such as the weak control on the final 3D shape, the lack of scalability and the lack of understanding on the short and long-term interactions among the units and cell behavior are yet to be further investigated.

\subsection{Integrative approach}

The combination of the top-down and bottom-up approaches constitutes a valuable strategy to increase the functionality of the devices for tissue engineering and achieve a multiscale control over the $3 \mathrm{D}$ substrate properties.

According to the integration between the bottom-up and top-down approaches, three sub-categories of integrative methods can be defined: i) sequential integration; ii) combination; and iii) technical integration - Fig. 5.

Employing an integrative approach could allow the increment of one or more feature/property in the scaffold without impairing the previous structure properties (Hollister and Murphy, 2011). Thereby, fully customizable constructs with multiple scales of complexity could be designed. With such ideal control and the increment of measurable properties, in silico modulation could contribute greatly for the understanding of the relationship between multiscale properties and cell behavior. Those resulting models would allow the mathematical prediction of cell behavior, contributing to the device optimization and eventually to the reduction of in vitro/in vivo experimentation costs (Walpole et al., 2013).

\subsubsection{Sequential integration}

3D constructs may be prepared using different techniques in a stepwise manner; i.e., by sequential integration. In these cases, the 3D structures are step-by-step prepared using at least one top-down and one bottom-up method. This category is the most used to overcome the lack of bioactivity and cell instruction of the traditional 3D scaffolds prepared by top-down approaches. Modification techniques such as adsorption, layer-by-layer assembling, self-assembling and grafting can be used to modify 3D scaffolds without impairing their initial features. Those methods have been used to include instructive cues such as adhesive proteins (Assmann et al., 2013; Choi et al., 2013; Ragetly et al., 2010; Truong et al., 2012), GFs (Crouzier et al., 2011; Macdonald et al., 2011; Shah et al., 2014; Tang et al., 2013), modular peptides (Lee et al., 2009) and bioactive calcium phosphate particles (Zhou et al., 2014). Controlling the biochemical environment and the incorporation 
of release system is manageable using sequential approaches; however, it is yet challenging to control the topographical cues on 3D top-down structures. The use of microfabrication techniques for the preparation of micro-layers of the substrate is an appealing solution. Several features might be controlled in each layer (biochemistry, topography, release system and cells), which are further assembled or stacked (Kolewe et al., 2013; Lima et al., 2014b). However, assembling and stabilizing those layers are still challenging as in the case of the bottom-up approaches.

\subsubsection{Combination}

Contrary to the other categories, in the integration by combination, the building blocks are incorporated prior to the processing and the top-down method is performed as if in absence of such units. Thereby, this approach allows the incorporation of new features, such as release systems in the bulk structure of the constructs. For instance, supercritical $\mathrm{CO}_{2}$ fluid foaming was used to prepare scaffolds of poly-L-lactic acid with nanoparticles carrying platelet lysate (Santo et al., 2012a). The incorporation of those bioactive nanoparticles enhanced the osteogenic differentiation of human adipose derived stem cells on the foams. Polymeric microcarriers, which allow a controlled expansion and formation of cellular aggregates, were successfully combined with gelatin methacrylamide-gellan gum bio-inks (Levato et al., 2014). With this combination, 3D scaffolds could be achieved with simultaneous high cell density, viability and improved mechanical performance.

\subsubsection{Technical integration}

The technical integration refers to the development of 3D constructs recurring to specialized equipment for simultaneous top-down and bottom-up processing. With such type of equipment's, topography, release system, biochemistry, shape and cells could be ideally controlled.

A foreseen example employing this approach could be the combination of rapid prototyping and spraying of small-units containing instructive or topographical cues. Recurring to a software-assisted deposition of both, shape controlled scaffolds with spatially defined topography, release systems and biochemistry could be fabricated. Though very appealing, such sophisticated technologies have yet to be developed.

\section{Conclusions and perspectives}

The major nano/micro-environment properties and events occurring in the normal and regenerative tissue have been inspiring the selection or synthesis of instructive cues to include in the 3D structures. However, there is still a need to understand which are the most effective spatial-temporal cues for each tissue. Besides the biochemistry, other scaffold features, e.g. topography, cells, cell anchorage and geometry, play major roles for the construct success both in vitro and in vivo. High-content screening of 3D scaffold properties and features promises a huge contribute in deciphering which cues, materials and methods will be more effective for the regeneration of each tissue (Hook et al., 2010; M.B. Oliveira et al., 2013, 2014; Simon and Lin-Gibson, 2011).

The control of all such features calls for processing approaches that allow a multiple scale control, i.e., integrative approaches. According to the combinations between the top-down and bottom-up techniques, different integrative approaches were defined: sequential, combination and technical integration. The assembling of building blocks in a single bottom-up approach is yet in its infancy, in regard to tissue engineering applications or the development of 3D tissue-models. However, their integration with top-down approaches, e.g. 3D printing, may accelerate their development and the preparation of a highly controlled multiscale $3 \mathrm{D}$ tissue engineering devices. The increase in complexity of the fabricated devices should also be balanced with the regulatory issues and commercial viability so that their realistic employment in the clinics could be envisaged.

\section{Acknowledgments}

The research leading to these results has received funding from the European Research Council grant agreement ERC-2012-ADG-20120216321266 for the project ComplexiTE. Portuguese Foundation for Science and Technology is gratefully acknowledged for the fellowship of Sara M. Oliveira (SFRH/BD/70107/2010).

\section{References}

Abe, H., Hara, Y., Maeda, S., Hashimoto, S., 2014a. Adhesion of gels by silica particle. J. Phys. Chem. B 118, 2518-2522.

Abe, H., Hara, Y., Maeda, S., Hashimoto, S., 2014b. Surface modification method for adhesion of gels. Chem. Lett. 43, 243-245.

Alves, N.M., Shi, J., Oramas, E., Santos, J.L., Tomas, H., Mano, J.F., 2009. Bioinspired superhydrophobic poly(L-lactic acid) surfaces control bone marrow derived cells adhesion and proliferation. J. Biomed. Mater. Res. A 91, 480-488.

Alves, N.M., Pashkuleva, I., Reis, R.L., Mano, J.F., 2010. Controlling cell behavior through the design of polymer surfaces. Small 6, 2208-2220.

Amorim, S., Pires, R.A., da Costa, D.S., Reis, R.L., Pashkuleva, I., 2013. Interactions between exogenous FGF-2 and sulfonic groups: in situ characterization and impact on the morphology of human adipose-derived stem cells. Langmuir 29, 7983-7992.

Anderson, J.M., Kushwaha, M., Tambralli, A., Bellis, S.L., Camata, R.P., Jun, H.W., 2009. Osteogenic differentiation of human mesenchymal stem cells directed by extracellular matrix-mimicking ligands in a biomimetic self-assembled peptide amphiphile nanomatrix. Biomacromolecules 10, 2935-2944.

Andia, I., Maffulli, N., 2013. Platelet-rich plasma for managing pain and inflammation in osteoarthritis. Nat. Rev. Rheumatol. 9, 721-730.

Anitua, E., Andia, I., Ardanza, B., Nurden, P., Nurden, A.T., 2004. Autologous platelets as a source of proteins for healing and tissue regeneration. Thromb. Haemost. 91, 4-15.

Arima, Y., Iwata, H., 2007. Effect of wettability and surface functional groups on protein adsorption and cell adhesion using well-defined mixed self-assembled monolayers. Biomaterials 28, 3074-3082.

Assmann, A., Delfs, C., Munakata, H., Schiffer, F., Horstkötter, K., Huynh, K., Barth, M., Stoldt, V.R., Kamiya, H., Boeken, U., 2013. Acceleration of autologous in vivo recellularization of decellularized aortic conduits by fibronectin surface coating. Biomaterials 34, 6015-6026.

Battiston, K.G., Cheung, J.W.C., Jain, D., Santerre, J.P., 2014. Biomaterials in co-culture systems: towards optimizing tissue integration and cell signaling within scaffolds. Biomaterials 35, 4465-4476.

Bernfield, M., Kokenyesi, R., Kato, M., Hinkes, M.T., Spring, J., Gallo, R.L., Lose, E.J., 1992. Biology of the syndecans: a family of transmembrane heparan sulfate proteoglycans. Annu. Rev. Cell Biol. 8, 365-393.

Bianco, P., Riminucci, M., Gronthos, S., Robey, P.G., 2001. Bone marrow stromal stem cells: nature, biology, and potential applications. Stem Cells 19, 180-192.

Bidan, C.M., Kommareddy, K.P., Rumpler, M., Kollmannsberger, P., Fratzl, P., Dunlop, J.W.C., 2013. Geometry as a factor for tissue growth: towards shape optimization of tissue engineering scaffolds. Adv. Healthc. Mater. 2, 186-194.

Biondi, M., Ungaro, F., Quaglia, F., Netti, P.A., 2008. Controlled drug delivery in tissue engineering. Adv. Drug Deliv. Rev. 60, 229-242.

Bitar, M., Brown, R.A., Salih, V., Kidane, A.G., Knowles, J.C., Nazhat, S.N., 2008. Effect of cell density on osteoblastic differentiation and matrix degradation of biomimetic dense collagen scaffolds. Biomacromolecules 9, 129-135.

Borges, J., Mano, J.F., 2014. Molecular interactions driving the layer-by-layer assembly of multilayers. Chem. Rev. 114, 8883-8942.

Borges, J., Rodrigues, L.C., Reis, R.L., Mano, J.F., 2014. Layer-by-layer assembly of light-responsive polymeric multilayer systems. Adv. Funct. Mater. 24, 5624-5648.

Borghi, N., Lowndes, M., Maruthamuthu, V., Gardel, M.L., Nelson, W.J., 2010. Regulation of cell motile behavior by crosstalk between cadherin- and integrin-mediated adhesions. Proc. Natl. Acad. Sci. U. S. A. 107, 13324-13329.

Brafman, D.A., 2013. Constructing stem cell microenvironments using bioengineering approaches. Physiol. Genomics 45, 1123-1135.

Cabezas, L.I., Gracia, I., de Lucas, A., Rodriguez, J.F., 2014. Novel model for the description of the controlled release of 5-fluorouracil from PLGA and PLA foamed scaffolds impregnated in supercritical $\mathrm{CO}_{2}$. Ind. Eng. Chem. Res. 53, 15374-15382.

Carey, DJd, 1997. Syndecans: multifunctional cell-surface co-receptors. Biochem. J. 327 (Pt 1), 1-16.

Caridade, S.G., Monge, C., Almodovar, J., Guillot, R., Lavaud, J., Josserand, V., Coll, J.L., Mano, J.F., Picart, C., 2015. Myoconductive and osteoinductive free-standing polysaccharide membranes. Acta Biomater. 15, 139-149.

Castro, E., Mano, J.F., 2013. Magnetic force-based tissue engineering and regenerative medicine. J. Biomed. Nanotechnol. 9, 1129-1136.

Ceylan, H., Kocabey, S., Unal Gulsuner, H., Balcik, O.S., Guler, M.O., Tekinay, A.B., 2014 Bone-like mineral nucleating peptide nanofibers induce differentiation of human mesenchymal stem cells into mature osteoblasts. Biomacromolecules 15, 2407-2418.

Chamberlain, G., Fox, J., Ashton, B., Middleton, J., 2007. Concise review: mesenchyma stem cells: their phenotype, differentiation capacity, immunological features, and potential for homing. Stem Cells 25, 2739-2749.

Chen, G.P., Sato, T., Ushida, T., Hirochika, R., Shirasaki, Y., Ochiai, N., Tateishi, T., 2003. The use of a novel PLGA fiber/collagen composite web as a scaffold for engineering of articular cartilage tissue with adjustable thickness. J. Biomed. Mater. Res. A 67A, 1170-1180.

Chen, C.S., Tan, J., Tien, J., 2004. Mechanotransduction at cell-matrix and cell-cell contacts. Annu. Rev. Biomed. Eng. 6, 275-302. 
Chen, C.H., Liu, J.M.J., Chua, C.K., Chou, S.M., Shyu, V.B.H., Chen, J.P., 2014a. Cartilage tissue engineering with silk fibroin scaffolds fabricated by indirect additive manufacturing technology. Materials 7, 2104-2119.

Chen, P.M., Liu, K.J., Hsu, P.J., Wei, C.F., Bai, C.H., Ho, L.J., Sytwu, H.K., Yen, B.L., 2014b. Induction of immunomodulatory monocytes by human mesenchymal stem cellderived hepatocyte growth factor through ERK1/2. J. Leukoc. Biol. 96, 295-303.

Chetprayoon, P., Kadowaki, K., Matsusaki, M., Akashi, M., 2013. Survival and structural evaluations of three-dimensional tissues fabricated by the hierarchical cell manipulation technique. Acta Biomater. 9, 4698-4706.

Chiu, L.L., Radisic, M., 2013. Cardiac tissue engineering. Curr. Opin. Chem. Eng. 2, 41-52.

Choi, Y., Chung, H., Jung, H., Couchman, J.R., Oh, E.S., 2011. Syndecans as cell surface receptors: unique structure equates with functional diversity. Matrix Biol. 30, 93-99.

Choi, S.K., Park, J.K., Lee, K.M., Lee, S.K., Jeon, W.B., 2013. Improved neural progenitor cell proliferation and differentiation on poly(lactide-co-glycolide) scaffolds coated with elastin-like polypeptide. J. Biomed. Mater. Res. B Appl. Biomater. 101, 1329-1339.

Chou, L., Firth, J.D., Uitto, V.J., Brunette, D.M., 1995. Substratum surface topography alters cell shape and regulates fibronectin mRNA level, mRNA stability, secretion and assembly in human fibroblasts. J. Cell Sci. 108 (Pt 4), 1563-1573.

Chung, S.E., Jung, Y., Kwon, S., 2011. Three-dimensional fluidic self-assembly by axis translation of two-dimensionally fabricated microcomponents in railed microfluidics. Small 7, 796-803.

Cinotti, G., Corsi, A., Sacchetti, B., Riminucci, M., Bianco, P., Giannicola, G., 2013. Bone ingrowth and vascular supply in experimental spinal fusion with platelet-rich plasma. Spine (Phila Pa 1976) 38, 385-391.

Claes, L., Recknagel, S., Ignatius, A., 2012. Fracture healing under healthy and inflammatory conditions. Nat. Rev. Rheumatol. 8, 133-143.

Clark, R.A., Ghosh, K., Tonnesen, M.G., 2007. Tissue engineering for cutaneous wounds J. Investig. Dermatol. 127, 1018-1029.

Cole, M.A., Voelcker, N.H., Thissen, H., Griesser, H.J., 2009. Stimuli-responsive interfaces and systems for the control of protein-surface and cell-surface interactions. Biomaterials 30, 1827-1850.

Cooke, M.E., Allon, A.A., Cheng, T., Kuo, A.C., Kim, H.T., Vail, T.P., Marcucio, R.S., Schneider, R.A., Lotz, J.C., Alliston, T., 2011. Structured three-dimensional co-culture of mesenchymal stem cells with chondrocytes promotes chondrogenic differentiation without hypertrophy. Osteoarthr. Cartil. 19, 1210-1218.

Coppinger, J.A., Cagney, G., Toomey, S., Kislinger, T., Belton, O., McRedmond, J.P., Cahill, D.J., Emili, A., Fitzgerald, D.J., Maguire, P.B., 2004. Characterization of the proteins released from activated platelets leads to localization of novel platelet proteins in human atherosclerotic lesions. Blood 103, 2096-2104.

Correia, C.R., Moreira-Teixeira, L.S., Moroni, L., Reis, R.L., van Blitterswijk, C.A., Karperien, M., Mano, J.F., 2011. Chitosan scaffolds containing hyaluronic acid for cartilage tissue engineering. Tissue Eng. Part C Methods 17, 717-730.

Correia, C., Grayson, W., Eton, R., Gimble, J.M., Sousa, R.A., Reis, R.L., VunjakNovakovic, G., 2012. Human adipose-derived cells can serve as a single-cel source for the in vitro cultivation of vascularized bone grafts. J. Tissue Eng. Regen. Med. 8, 629-639.

Correia, C.R., Reis, R.L., Mano, J.F., 2013. Multilayered hierarchical capsules providing cell adhesion sites. Biomacromolecules 14, 743-751.

Correlo, V.M., Boesel, L.F., Pinho, E., Costa-Pinto, A.R., Alves da Silva, M.L., Bhattacharya, M. Mano, J.F., Neves, N.M., Reis, R.L., 2009. Melt-based compression-molded scaffolds from chitosan-polyester blends and composites: morphology and mechanical properties. J. Biomed. Mater. Res. A 91, 489-504.

Costa, R.R., Mano, J.F., 2014. Polyelectrolyte multilayered assemblies in biomedical technologies. Chem. Soc. Rev. 43, 3453-3479.

Costa, R.R., Custodio, C.A., Testera, A.M., Arias, F.J., Rodríguez-Cabello, J.C., Alves, N.M., Mano, J.F., 2009. Stimuli-responsive thin coatings using elastin-like polymers for biomedical applications. Adv. Funct. Mater. 19, 3210-3218.

Costa, R.R., Castro, E., Arias, F.J., Rodriguez-Cabello, J.C., Mano, J.F., 2013. Multifunctional compartmentalized capsules with a hierarchical organization from the nano to the macro scales. Biomacromolecules 14, 2403-2410.

Crouzier, T., Sailhan, F., Becquart, P., Guillot, R., Logeart-Avramoglou, D., Picart, C., 2011. The performance of BMP-2 loaded TCP/HAP porous ceramics with a polyelectrolyte multilayer film coating. Biomaterials 32, 7543-7554.

Custodio, C.A., Alves, C.M., Reis, R.L., Mano, J.F., 2010. Immobilization of fibronectin in chitosan substrates improves cell adhesion and proliferation. J. Tissue Eng. Regen. Med. $4,316-323$

Custódio, C., Santo, V., Oliveira, M., Gomes, M., Reis, R., Mano, J., 2014. Functionalized microparticles producing scaffolds in combination with cells. Adv. Funct. Mater. 24 $1391-1400$.

Custodio, C.A., Reis, R.L., Mano, J.F., 2014a. Engineering biomolecular microenvironments for cell instructive biomaterials. Adv. Healthc. Mater. 3, 797-810.

Custodio, C.A., San Miguel-Arranz, V., Gropeanu, R.A., Gropeanu, M., Wirkner, M., Reis, R.L. Mano, J.F., del Campo, A., 2014b. Photopatterned antibodies for selective cell attachment. Langmuir 30, 10066-10071.

Custodio, C.A., Cerqueira, M.T., Marques, A.P., Reis, R.L., Mano, J.F., 2015. Cell selective chitosan microparticles as injectable cell carriers for tissue regeneration. Biomaterials 43, 23-31.

da Costa, D.S., Pires, R.A., Frias, A.M., Reis, R.L., Pashkuleva, I., 2012. Sulfonic groups induce formation of filopodia in mesenchymal stem cells. J. Mater. Chem. 22, 7172-7178.

da Silva, R.M., Mano, J.F., Reis, R.L., 2007. Smart thermoresponsive coatings and surfaces for tissue engineering: switching cell-material boundaries. Trends Biotechnol. 25, 577-583.

Dar, A., Shachar, M., Leor, J., Cohen, S., 2002. Optimization of cardiac cell seeding and distribution in 3D porous alginate scaffolds. Biotechnol. Bioeng. 80, 305-312.

Deschner, R., Tang, H., Allen, P., Hall, C., Hlis, R., Ellington, A., Willson, C.G., 2014. Progress report on the generation of polyfunctional microscale particles for programmed selfassembly. Chem. Mater. 26, 1457-1462.
Discher, D.E., Mooney, D.J., Zandstra, P.W., 2009. Growth factors, matrices, and forces combine and control stem cells. Science 324, 1673-1677.

Du, Y., Lo, E., Ali, S., Khademhosseini, A., 2008. Directed assembly of cell-laden microgels for fabrication of 3D tissue constructs. Proc. Natl. Acad. Sci. U. S. A. 105, 9522-9527.

Duarte, A.R.C., Mano, J.F., Reis, R.L., 2009a. Preparation of chitosan scaffolds loaded with dexamethasone for tissue engineering applications using supercritical fluid technology. Eur. Polym. J. 45, 141-148.

Duarte, A.R.C., Mano, J.F., Reis, R.L., 2009b. Perspectives on: supercritical fluid technology for 3D tissue engineering scaffold applications. J. Bioact. Compat. Polym. 24, 385-400.

Duarte, A.R.C., Mano, J.F., Reis, R.L., 2012. The role of organic solvent on the preparation of chitosan scaffolds by supercritical assisted phase inversion. J. Supercrit. Fluids 72, 326-332.

Dvir, T., Timko, B.P., Kohane, D.S., Langer, R., 2011. Nanotechnological strategies for engineering complex tissues. Nat. Nanotechnol. 6, 13-22.

Engler, A.J., Sen, S., Sweeney, H.L., Discher, D.E., 2006. Matrix elasticity directs stem cell lineage specification. Cell 126, 677-689.

Enoch, S., Leaper, D.J., 2008. Basic science of wound healing. Surgery (Oxford) 26, 31-37.

Epstein, F.H., Singer, A.J., Clark, R.A., 1999. Cutaneous wound healing. N. Engl. J. Med. 341, 738-746.

Fink, J., Fuhrmann, R., Scharnweber, T., Franke, R.P., 2008. Stimulation of monocytes and macrophages: possible influence of surface roughness. Clin. Hemorheol. Microcirc. 39, 205-212.

Forbes, S.J., Rosenthal, N., 2014. Preparing the ground for tissue regeneration: from mechanism to therapy. Nat. Med. 20, 857-869.

Franz, S., Rammelt, S., Scharnweber, D., Simon, J.C., 2011. Immune responses to implants-a review of the implications for the design of immunomodulatory biomaterials. Biomaterials 32, 6692-6709.

Gao, P., Nie, X., Zou, M., Shi, Y., Cheng, G., 2011. Recent advances in materials for extended-release antibiotic delivery system. J. Antibiot. (Tokyo) 64, 625-634

García Cruz, D.M., Escobar Ivirico, J.L., Gomes, M.M., Gómez Ribelles, J.L., Sánchez, M.S., Reis, R.L., Mano, J.F., 2008. Chitosan microparticles as injectable scaffolds for tissue engineering. J. Tissue Eng. Regen. Med. 2, 378-380.

Gattazzo, F., Urciuolo, A., Bonaldo, P., 2014. Extracellular matrix: a dynamic microenvironment for stem cell niche. Biochim. Biophys. Acta 1840, 2506-2519.

Gawaz, M., Vogel, S., 2013. Platelets in tissue repair: control of apoptosis and interactions with regenerative cells. Blood 122, 2550-2554.

Gil, S., Mano, J.F., 2014. Magnetic composite biomaterials for tissue engineering. Biomater. Sci. 2, 812-818.

Gilde, F., Maniti, O., Guillot, R., Mano, J.F., Logeart-Avramoglou, D., Sailhan, F., Picart, C., 2012. Secondary structure of rhBMP-2 in a protective biopolymeric carrier material. Biomacromolecules 13, 3620-3626.

Gitay-Goren, H., Soker, S., Vlodavsky, I., Neufeld, G., 1992. The binding of vascular endothelial growth factor to its receptors is dependent on cell surface-associated heparin-like molecules. J. Biol. Chem. 267, 6093-6098.

Gittens, R.A., Scheideler, L., Rupp, F., Hyzy, S.L., Geis-Gerstorfer, J., Schwartz, Z., Boyan, B.D., 2014. A review on the wettability of dental implant surfaces II: biological and clinical aspects. Acta Biomater. 10, 2907-2918.

Gosain, A., DiPietro, L.A., 2004. Aging and wound healing. World J. Surg. 28, 321-326.

Groeber, F., Holeiter, M., Hampel, M., Hinderer, S., Schenke-Layland, K., 2011. Skin tissue engineering-in vivo and in vitro applications. Adv. Drug Deliv. Rev. 63, 352-366.

Guilak, F., Cohen, D.M., Estes, B.T., Gimble, J.M., Liedtke, W., Chen, C.S., 2009. Control of stem cell fate by physical interactions with the extracellular matrix. Cell Stem Cell 5, 17-26.

Gumbiner, B.M., 1996. Cell adhesion: the molecular basis of tissue architecture and morphogenesis. Cell 84, 345-357.

Guo, S., Dipietro, L.A., 2010. Factors affecting wound healing. J. Dent. Res. 89, 219-229.

Haik, S., Gauthier, L.R., Granotier, C., Peyrin, J.-M., Lages, C.S., Dormont, D., Boussin, F.D., 2000. Fibroblast growth factor 2 up regulates telomerase activity in neural precursor cells. Oncogene 19, 2957-2966.

Hampson, K., Forsyth, N., El Haj, A., Maffulli, N., 2008. Tendon tissue engineering. Top. Tissue Eng. 4

Han, Y.L., Yang, Y., Liu, S., Wu, J., Chen, Y., Lu, T.J., Xu, F., 2013. Directed self-assembly of microscale hydrogels by electrostatic interaction. Biofabrication 5, 035004.

Han, Y.L., Wang, S., Zhang, X., Li, Y., Huang, G., Qi, H., Pingguan-Murphy, B., Li, Y., Lu, T.J., $\mathrm{Xu}, \mathrm{F} ., 2$ 2014. Engineering physical microenvironment for stem cell based regenerative medicine. Drug Discov. Today 19, 763-773.

Hanson, S., D'Souza, R.N., Hematti, P., 2014. Biomaterial-mesenchymal stem cell constructs for immunomodulation in composite tissue engineering. Tissue Eng. A 20, 2162-2168.

Healy, K.E., Guldberg, R.E., 2007. Bone tissue engineering. J. Musculoskelet. Neuronal Interact. 7, 328-330.

Hench, L.L., Polak, J.M., 2002. Third-generation biomedical materials. Science 295, 1014-1017.

Hersel, U., Dahmen, C., Kessler, H., 2003. RGD modified polymers: biomaterials for stimulated cell adhesion and beyond. Biomaterials 24, 4385-4415.

Hetrick, E.M., Prichard, H.L., Klitzman, B., Schoenfisch, M.H., 2007. Reduced foreign body response at nitric oxide-releasing subcutaneous implants. Biomaterials 28, 4571-4580.

Ho, M.H., Kuo, P.Y., Hsieh, H.J., Hsien, T.Y., Hou, L.T., Lai, J.Y., Wang, D.M., 2004. Preparation of porous scaffolds by using freeze-extraction and freeze-gelation methods. Biomaterials $25,129-138$.

Hollister, S.J., Murphy, W.L., 2011. Scaffold translation: barriers between concept and clinic. Tissue Eng. B Rev. 17, 459-474.

Hook, A.L., Anderson, D.G., Langer, R., Williams, P., Davies, M.C., Alexander, M.R., 2010. High throughput methods applied in biomaterial development and discovery. Biomaterials 31, 187-198.

Hosseini, V., Kollmannsberger, P., Ahadian, S., Ostrovidov, S., Kaji, H., Vogel, V., Khademhosseini, A., 2014. Fiber-assisted molding (FAM) of surfaces with tunable 
curvature to guide cell alignment and complex tissue architecture. Small 10 4851-4857.

Hsu, S.H., Huang, G.S., 2013. Substrate-dependent Wnt signaling in MSC differentiation within biomaterial-derived 3D spheroids. Biomaterials 34, 4725-4738.

Huang, G.S., Hsieh, P.S., Tseng, C.S., Hsu, S.H., 2014. The substrate-dependent regeneration capacity of mesenchymal stem cell spheroids derived on various biomaterial surfaces. Biomater. Sci. 2, 1652-1660.

Humphries, J.D., Byron, A., Humphries, M.J., 2006. Integrin ligands at a glance. J. Cell Sci. $119,3901-3903$

Hutmacher, D.W., Schantz, T., Zein, I., Ng, K.W., Teoh, S.H., Tan, K.C., 2001. Mechanical properties and cell cultural response of polycaprolactone scaffolds designed and fabricated via fused deposition modeling. J. Biomed. Mater. Res. 55, 203-216.

Hutmacher, D.W., Sittinger, M., Risbud, M.V., 2004. Scaffold-based tissue engineering: rationale for computer-aided design and solid free-form fabrication systems. Trends Biotechnol. 22, 354-362.

Hynes, R.O., 2002. Integrins: bidirectional, allosteric signaling machines. Cell 110 , 673-687.

Jan, E., Kotov, N.A., 2007. Successful differentiation of mouse neural stem cells on layer-bylayer assembled single-walled carbon nanotube composite. Nano Lett. 7, 1123-1128.

Johnson, N.R., Wang, Y., 2013. Controlled delivery of heparin-binding EGF-like growth factor yields fast and comprehensive wound healing. J. Control. Release 166, 124-129.

Jones, D.L., Wagers, A.J., 2008. No place like home: anatomy and function of the stem cell niche. Nat. Rev. Mol. Cell Biol. 9, 11-21.

Jones, J.A., Chang, D.T., Meyerson, H., Colton, E., Kwon, I.K., Matsuda, T., Anderson, J.M., 2007. Proteomic analysis and quantification of cytokines and chemokines from biomaterial surface-adherent macrophages and foreign body giant cells. J. Biomed. Mater. Res. A 83, 585-596.

Kamath, S., Blann, A.D., Lip, G.Y., 2001. Platelet activation: assessment and quantification. Eur. Heart J. 22, 1561-1571.

Kao, W.J., Lee, D., 2001. In vivo modulation of host response and macrophage behavior by polymer networks grafted with fibronectin-derived biomimetic oligopeptides: the role of RGD and PHSRN domains. Biomaterials 22, 2901-2909.

Kao, W.J., Liu, Y., 2001. Utilizing biomimetic oligopeptides to probe fibronectin-integrin binding and signaling in regulating macrophage function in vitro and in vivo. Front. Biosci. 6, D992-D999.

Karageorgiou, V., Kaplan, D., 2005. Porosity of 3D biomaterial scaffolds and osteogenesis. Biomaterials 26, 5474-5491.

Karp, J.M., Sarraf, F., Shoichet, M.S., Davies, J.E., 2004. Fibrin-filled scaffolds for bone-tissue engineering: an in vivo study. J. Biomed. Mater. Res. A 71, 162-171.

Kassolis, J.D., Rosen, P.S., Reynolds, M.A., 2000. Alveolar ridge and sinus augmentation utilizing platelet-rich plasma in combination with freeze-dried bone allograft: case series. J. Periodontol. 71, 1654-1661.

Kasten, P., Beyen, I., Niemeyer, P., Luginbühl, R., Bohner, M., Richter, W., 2008. Porosity and pore size of $\beta$-tricalcium phosphate scaffold can influence protein production and osteogenic differentiation of human mesenchymal stem cells: an in vitro and in vivo study. Acta Biomater. 4, 1904-1915.

Katayama, S., Maeda, S., Hara, Y., Hashimoto, S., 2013. A Self-assembling Method for Polymer Gel Components.

Kawase, T., Okuda, K., Wolff, L.F., Yoshie, H., 2003. Platelet-rich plasma-derived fibrin clot formation stimulates collagen synthesis in periodontal ligament and osteoblastic cells in vitro. J. Periodontol. 74, 858-864.

Kehrl, J.H., Roberts, A.B., Wakefield, L.M., Jakowlew, S., Sporn, M.B., Fauci, A.S., 1986. Transforming growth-factor-beta is an important immunomodulatory protein for human-beta lymphocytes-B. J. Immunol. 137, 3855-3860.

Kern, S., Eichler, H., Stoeve, J., Kluter, H., Bieback, K., 2006. Comparative analysis of mesenchymal stem cells from bone marrow, umbilical cord blood, or adipose tissue. Stem Cells 24, 1294-1301.

Kilian, K.A., Bugarija, B., Lahn, B.T., Mrksich, M., 2010. Geometric cues for directing the differentiation of mesenchymal stem cells. Proc. Natl. Acad. Sci. U. S. A. 107, 4872-4877.

Kim, S.H., Turnbull, J., Guimond, S., 2011. Extracellular matrix and cell signalling: the dynamic cooperation of integrin, proteoglycan and growth factor receptor. J. Endocrinol. 209, 139-151.

Kim, K. Lam, J., Lu, S., Spicer, P.P., Lueckgen, A.. Tabata, Y., Wong, M.E., Jansen, J.A., Mikos, A.G., Kasper, F.K., 2013. Osteochondral tissue regeneration using a bilayered composite hydrogel with modulating dual growth factor release kinetics in a rabbit model. J. Control. Release 168, 166-178

Kim, Y.-H., Furuya, H., Tabata, Y., 2014a. Enhancement of bone regeneration by dual release of a macrophage recruitment agent and platelet-rich plasma from gelatin hydrogels. Biomaterials 35, 214-224.

Kim, Y.K., Oue, R., Wang, S.W. Liu, W.F. 2014b. Modification of biomaterials with a selfprotein inhibits the macrophage response. Adv. Healthc. Mater. 3, 989-994.

King, W.J., Krebsbach, P.H., 2012. Growth factor delivery: how surface interactions modulate release in vitro and in vivo. Adv. Drug Deliv. Rev. 64, 1239-1256.

Kolesky, D.B., Truby, R.L., Gladman, A.S., Busbee, T.A., Homan, K.A., Lewis, J.A., 2014. 3D bioprinting of vascularized, heterogeneous cell-laden tissue constructs. Adv. Mater. 26, 3124-3130.

Kolewe, M.E., Park, H., Gray, C., Ye, X., Langer, R., Freed, L.E., 2013. 3D structural patterns in scalable, elastomeric scaffolds guide engineered tissue architecture. Adv. Mater. 25, 4459-4465.

Koshy, S.T., Ferrante, T.C., Lewin, S.A., Mooney, D.J., 2014. Injectable, porous, and cellresponsive gelatin cryogels. Biomaterials 35, 2477-2487.

Kretlow, J.D., Klouda, L., Mikos, A.G., 2007. Injectable matrices and scaffolds for drug delivery in tissue engineering. Adv. Drug Deliv. Rev. 59, 263-273.

Kreuger, J., Spillmann, D., Li, J.P., Lindahl, U., 2006. Interactions between heparan sulfate and proteins: the concept of specificity. J. Cell Biol. 174, 323-327.
Lacroix, D., Chateau, A., Ginebra, M.P., Planell, J.A., 2006. Micro-finite element models of bone tissue-engineering scaffolds. Biomaterials 27, 5326-5334.

Lambert, M., Padilla, F., Mege, R.M., 2000. Immobilized dimers of N-cadherin-Fc chimera mimic cadherin-mediated cell contact formation: contribution of both outside-in and inside-out signals. J. Cell Sci. 113, 2207-2219.

Landers, R., Hubner, U., Schmelzeisen, R., Mulhaupt, R., 2002. Rapid prototyping of scaffolds derived from thermoreversible hydrogels and tailored for applications in tissue engineering. Biomaterials 23, 4437-4447.

Lane, S.W., Williams, D.A., Watt, F.M., 2014. Modulating the stem cell niche for tissue regeneration. Nat. Biotechnol. 32, 795-803.

Langer, R., Vacanti, J.P., 1993. Tissue engineering. Science 260, 920-926.

anza, R., Langer, R., Vacanti, J.P., 2011. Principles of Tissue Engineering. Academic Press.

Larsson, S., Hannink, G., 2011. Injectable bone-graft substitutes: current products, their characteristics and indications, and new developments. Injury 42, S30-S34.

Lee, C.M., Hu, J., 2013. Cell density during differentiation can alter the phenotype of bone marrow-derived macrophages. Cell Biosci. 3, 30

Lee, J.S., Lee, J.S., Wagoner-Johnson, A., Murphy, W.L., 2009. Modular peptide growth factors for substrate-mediated stem cell differentiation. Angew. Chem. Int. Ed. Engl. 48 6266-6269.

Lemmon, M.A., Schlessinger, J., 2010. Cell signaling by receptor tyrosine kinases. Cell 141 $1117-1134$.

Leng, L., McAllister, A., Zhang, B., Radisic, M., Gunther, A., 2012. Mosaic hydrogels: onestep formation of multiscale soft materials. Adv. Mater. 24, 3650-3658.

Levato, R., Visser, J., Planell, J.A., Engel, E., Malda, J., Mateos-Timoneda, M.A., 2014 Biofabrication of tissue constructs by 3D bioprinting of cell-laden microcarriers. Biofabrication 6, 035020

Li, H., Chang, J., 2005. Preparation, characterization and in vitro release of gentamicin from PHBV/wollastonite composite microspheres. J. Control. Release 107, 463-473.

Li, L., Xie, T. 2005. Stem cell niche: structure and function. Annu. Rev. Cell Dev. Biol. 21 605-631.

Li, Z., Liu, C., Xie, Z., Song, P., Zhao, R.C., Guo, L., Liu, Z., Wu, Y., 2011. Epigenetic dysregulation in mesenchymal stem cell aging and spontaneous differentiation. PLoS One 6 e20526.

Lima, A.C., Sher, P., Mano, J.F., 2012. Production methodologies of polymeric and hydrogel particles for drug delivery applications. Expert Opin. Drug Deliv. 9 $231-248$

Lima, M.J., Pirraco, R.P., Sousa, R.A., Neves, N.M., Marques, A.P., Bhattacharya, M., Correlo, V.M., Reis, R.L, 2014. Bottom-up approach to construct microfabricated multi-layer scaffolds for bone tissue engineering. Biomed. Microdevices 16, 69-78.

Lima, A.C., Mano, J.F., Concheiro, A., Alvarez-Lorenzo, C., 2015. Fast and mild strategy, using superhydrophobic surfaces, to produce collagen/platelet lysate gel beads for skin regeneration. Stem Cell Rev. 11 (1), 161-179.

Lin, C.Y., Kikuchi, N., Hollister, S.J., 2004. A novel method for biomaterial scaffold internal architecture design to match bone elastic properties with desired porosity. J. Biomech. 37, 623-636.

Liu, W., Li, Y., Feng, S., Ning, J., Wang, J., Gou, M., Chen, H., Xu, F., Du, Y., 2014. Magnetically controllable 3D microtissues based on magnetic microcryogels. Lab Chip 14 2614-2625.

Lord, M.S., Foss, M., Besenbacher, F., 2010. Influence of nanoscale surface topography on protein adsorption and cellular response. Nano Today 5, 66-78.

Lucker, P.B., Javaherian, S., Soleas, J.P., Halverson, D., Zandstra, P.W., McGuigan, A.P., 2014. A microgroove patterned multiwell cell culture plate for high-throughput studies of cell alignment. Biotechnol. Bioeng. 111, 2537-2548.

Lutolf, M.P. Hubbell, J.A., 2005. Synthetic biomaterials as instructive extracellular microenvironments for morphogenesis in tissue engineering. Nat. Biotechnol. 23, 47-55.

Lutolf, M.P., Gilbert, P.M.. Blau, H.M., 2009. Designing materials to direct stem-cell fate. Nature 462, 433-441.

Macdonald, M.L., Samuel, R.E., Shah, N.J., Padera, R.F., Beben, Y.M., Hammond, P.T., 2011 Tissue integration of growth factor-eluting layer-by-layer polyelectrolyte multilayer coated implants. Biomaterials 32, 1446-1453.

Madduri, S., Gander, B., 2012. Growth factor delivery systems and repair strategies for damaged peripheral nerves. J. Control. Release 161, 274-282.

Makrydima, S.F., Pistiki, A.C., Chrelias, C.G., Sioulas, V.D., Siristatidis, C.S., GiamarellosBourboulis, E.J., Kassanos, D.P., 2014. The immunomodulatory and anti-apoptotic effect of dexamethasone in imminent preterm labor: an experimental study. Eur. J. Pharmacol. 730, 31-35.

Mano, J.F., 2008. Stimuli-responsive polymeric systems for biomedical applications. Adv. Eng. Mater. 10, 515-527.

Mano, J.F., 2015. Designing biomaterials for tissue engineering based on the deconstruction of the native cellular environment Mater. Lett. 141, 198-202.

Mano, J.F., Reis, R.L., 2007. Osteochondral defects: present situation and tissue engineering approaches. J. Tissue Eng. Regen. Med. 1, 261-273.

Mano, J.F., Hungerford, G., Ribelles, J.L.G., 2008. Bioactive poly(L-lactic acid)-chitosan hybrid scaffolds. Mater. Sci. Eng. C Biomim. Supramol. Syst. 28, 1356-1365.

Marklein, R.A., Burdick, J.A., 2010. Controlling stem cell fate with material design. Adv. Mater. 22, 175-189.

Martins, G.V., Merino, E.G., Mano, J.F, Alves, N.M. 2010. Crosslink effect and albumin adsorption onto chitosan/alginate multilayered systems: an in situ QCM-D study. Macromol. Biosci. 10, 1444-1455.

Marx, R.E., Carlson, E.R., Eichstaedt, R.M., Schimmele, S.R., Strauss, J.E., Georgeff, K.R., 1998 Platelet-rich plasma: growth factor enhancement for bone grafts. Oral Surg. Oral Med. Oral Pathol. Oral Radiol. Endod. 85, 638-646.

Massia, S.P., Hubbell, J.A., 1990. Covalent surface immobilization of Arg-Gly-Asp-and TyrIle-Gly-Ser-Arg-containing peptides to obtain well-defined cell-adhesive substrates. Anal. Biochem. 187, 292-301. 
Massia, S.P., Hubbell, J.A., 1991. An RGD spacing of $440 \mathrm{~nm}$ is sufficient for integrin alpha V beta 3-mediated fibroblast spreading and $140 \mathrm{~nm}$ for focal contact and stress fiber formation. J. Cell Biol. 114, 1089-1100.

Masur, S.K., Dewal, H.S., Dinh, T.T., Erenburg, I., Petridou, S., 1996. Myofibroblasts differentiate from fibroblasts when plated at low density. Proc. Natl. Acad. Sci. U. S. A. 93, 4219-4223.

Matsusaki, M., 2012. Development of three-dimensional tissue models based on hierarchical cell manipulation using nanofilms. Bull. Chem. Soc. Jpn. 85, 401-414.

McBeath, R., Pirone, D.M., Nelson, C.M., Bhadriraju, K., Chen, C.S., 2004. Cell shape, cytoskeletal tension, and RhoA regulate stem cell lineage commitment. Dev. Cell 6 483-495.

McCloskey, K.E., 2013. Emerging Trends in Cell and Gene Therapy. Springer, pp. 471-483.

McGuigan, A.P., Sefton, M.V., 2006. Vascularized organoid engineered by modular assembly enables blood perfusion. Proc. Natl. Acad. Sci. U. S. A. 103, 11461-11466.

Mehta, M., Schmidt-Bleek, K., Duda, G.N., Mooney, D.J., 2012. Biomaterial delivery of morphogens to mimic the natural healing cascade in bone. Adv. Drug Deliv. Rev. 64, 1257-1276.

Melchels, F.P.W., Domingos, M.A.N., Klein, T.J., Malda, J., Bartolo, P.J., Hutmacher, D.W. 2012. Additive manufacturing of tissues and organs. Prog. Polym. Sci. 37, 1079-1104.

Mendonca, R.J., Coutinho-Netto, J., 2009. Cellular aspects of wound healing. An. Bras Dermatol. 84, 257-262.

Meng, H.G., Liao, J.H., Zhou, Y.H., Zhang, Q.M., 2009. Laser micro-processing of cardiovascular stent with fiber laser cutting system. Opt. Laser Technol. 41, 300-302.

Menke, N.B., Ward, K.R., Witten, T.M., Bonchev, D.G., Diegelmann, R.F., 2007. Impaired wound healing. Clin. Dermatol. 25, 19-25.

Miranda, E.S., Silva, T.H., Reis, R.L., Mano, J.F., 2011. Nanostructured natural-based polyelectrolyte multilayers to agglomerate chitosan particles into scaffolds for tissue engineering. Tissue Eng. A 17, 2663-2674.

Mizuno, M., Kuboki, Y., 2001. Osteoblast-related gene expression of bone marrow cells during the osteoblastic differentiation induced by type I collagen. J. Biochem. 129, 133-138.

Mokarram, N., Bellamkonda, R.V., 2014. A perspective on immunomodulation and tissue repair. Ann. Biomed. Eng. 42, 338-351.

Moore, K.A., Lemischka, I.R., 2006. Stem cells and their niches. Science 311, 1880-1885.

Mota, J., Yu, N., Caridade, S.G., Luz, G.M., Gomes, M.E., Reis, R.L., Jansen, J.A., Walboomers, X.F., Mano, J.F., 2012. Chitosan/bioactive glass nanoparticle composite membranes for periodontal regeneration. Acta Biomater. 8, 4173-4180.

Nakatsuji, N., 2013. Mesoscopic science, where materials become life and life inspires materials. A great opportunity to push back the frontiers of life, materials, and biomaterials sciences. Biomater. Sci. 1, 9-10.

Neto, A.I., Custódio, C.A., Song, W., Mano, J.F., 2011. High-throughput evaluation of interactions between biomaterials, proteins and cells using patterned superhydrophobic substrates. Soft Matter 7, 4147-4151.

Neto, A.I., Cibrao, A.C., Correia, C.R., Carvalho, R.R., Luz, G.M., Ferrer, G.G., Botelho, G., Picart, C., Alves, N.M., Mano, J.F., 2014. Nanostructured polymeric coatings based on chitosan and dopamine-modified hyaluronic acid for biomedical applications. Smal 10, 2459-2469.

Nichol, J.W., Khademhosseini, A., 2009. Modular tissue engineering: engineering biological tissues from the bottom up. Soft Matter 5, 1312-1319.

Nigam, S.K., Bush, K.T., 2014. Growth factor-heparan sulfate "switches" regulating stages of branching morphogenesis. Pediatr. Nephrol. 29, 727-735.

Odorico, J.S., Kaufman, D.S., Thomson, J.A., 2001. Multilineage differentiation from human embryonic stem cell lines. Stem Cells 19, 193-204.

Oh, S.H., Park, I.K., Kim, J.M., Lee, J.H., 2007. In vitro and in vivo characteristics of PCL scaffolds with pore size gradient fabricated by a centrifugation method. Biomaterials 28 1664-1671

Oh, J., Lee, Y.D., Wagers, A.J., 2014. Stem cell aging: mechanisms, regulators and therapeutic opportunities. Nat. Med. 20, 870-880.

Oliveira, M.B., Mano, J.F., 2011. Polymer-based microparticles in tissue engineering and regenerative medicine. Biotechnol. Prog. 27, 897-912.

Oliveira, M.B., Mano, J.F., 2014. High-throughput screening for integrative biomaterials design: exploring advances and new trends. Trends Biotechnol. 32, 627-636.

Oliveira, M.B., Song, W.L., Martin, L., Oliveira, S.M., Caridade, S.G., Alonso, M., Rodriguez Cabello, J.C., Mano, J.F., 2011a. Development of an injectable system based on elastin-like recombinamer particles for tissue engineering applications. Soft Matter 7, 6426-6434

Oliveira, S.M., Song, W., Alves, N.M., Mano, J.F., 2011b. Chemical modification of bioinspired superhydrophobic polystyrene surfaces to control cell attachment/proliferation. Soft Matter 7, 8932-8941.

Oliveira, M.B., Salgado, C.L., Song, W., Mano, J.F., 2013a. Combinatorial on-chip study of miniaturized 3D porous scaffolds using a patterned superhydrophobic platform. Small 9, 768-778.

Oliveira, S.M., Silva, T.H., Reis, R.L., Mano, J.F., 2013b. Nanocoatings containing sulfated polysaccharides prepared by layer-by-layer assembly as models to study cell-material interactions. J. Mater. Chem. B 1, 4406-4418.

Oliveira, S.M., Silva, T.H., Reis, R.L., Mano, J.F., 2013c. Hierarchical fibrillar scaffolds obtained by non-conventional layer-by-layer electrostatic self-assembly. Adv. Healthc Mater. 2, 422-427.

Oliveira, M.B., Ribeiro, M.P., Miguel, S.P., Neto, A.I., Coutinho, P., Correia, I.J., Mano, J.F., 2014a. In vivo high-content evaluation of three-dimensional scaffolds biocompatibility. Tissue Eng. C Methods 20, 851-864.

Oliveira, S.M., Alves, N.M., Mano, J.F., 2014b. Cell interactions with superhydrophilic and superhydrophobic surfaces. J. Adhes. Sci. Technol. 28, 843-863.

Oliveira, S.M., Reis, R.L., Mano, J.F., 2015a. Assembling human platelet lysate into multiscale 3D scaffolds for bone tissue engineering. ACS Biomater. Sci. Eng. 1, $2-6$.
Oliveira, S.M., Santo, V.E., Gomes, M.E., Reis, R.L., Mano, J.F., 2015b. Layer-by-layer assembled cell instructive nanocoatings containing platelet lysate. Biomaterials 48 , $56-65$

Park, S.H., Kim, T.G., Kim, H.C., Yang, D.Y., Park, T.G., 2008. Development of dual scale scaffolds via direct polymer melt deposition and electrospinning for applications in tissue regeneration. Acta Biomater. 4, 1198-1207.

Park, S.H., Koh, U.H., Kim, M., Yang, D.Y., Suh, K.Y., Shin, J.H., 2014. Hierarchical multilayer assembly of an ordered nanofibrous scaffold via thermal fusion bonding. Biofabrication 6, 024107.

Patil, S.D., Papadmitrakopoulos, F., Burgess, D.J., 2007. Concurrent delivery of dexamethasone and VEGF for localized inflammation control and angiogenesis. J. Control. Release 117, 68-79.

Perets, A., Baruch, Y., Weisbuch, F., Shoshany, G., Neufeld, G., Cohen, S., 2003. Enhancing the vascularization of three-dimensional porous alginate scaffolds by incorporating controlled release basic fibroblast growth factor microspheres. J. Biomed. Mater. Res. A 65, 489-497.

Poumay, Y., Pittelkow, M.R., 1995. Cell density and culture factors regulate keratinocyte commitment to differentiation and expression of suprabasal K1/K10 keratins. J. Investig. Dermatol. 104, 271-276.

Prabaharan, M., Mano, J.F., 2005. Hydroxypropyl chitosan bearing beta-cyclodextrin cavities: synthesis and slow release of its inclusion complex with a model hydrophobic drug. Macromol. Biosci. 5, 965-973.

Prabaharan, M., Reis, R.L., Mano, J.F., 2007a. Carboxymethyl chitosan-graftphosphatidylethanolamine: amphiphilic matrices for controlled drug delivery. React. Funct. Polym. 67, 43-52

Prabaharan, M., Rodriguez-Perez, M.A., de Saja, J.A., Mano, J.F., 2007b. Preparation and characterization of poly(L-lactic acid)-chitosan hybrid scaffolds with drug release capability. J. Biomed. Mater. Res. B Appl. Biomater. 81, 427-434.

Qi, H., Ghodousi, M., Du, Y., Grun, C., Bae, H., Yin, P., Khademhosseini, A., 2013. DNA-directed self-assembly of shape-controlled hydrogels. Nat. Commun. 4, 2275.

Raffaini, G., Ganazzoli, F., 2013. Surface topography effects in protein adsorption on nanostructured carbon allotropes. Langmuir 29, 4883-4893.

Ragetly, G., Griffon, D.J., Chung, Y.S., 2010. The effect of type II collagen coating of chitosan fibrous scaffolds on mesenchymal stem cell adhesion and chondrogenesis. Acta Biomater. 6, 3988-3997.

Reilly, G.C., Engler, A.J., 2010. Intrinsic extracellular matrix properties regulate stem cell differentiation. J. Biomech. 43, 55-62.

Richardson, T.P., Peters, M.C., Ennett, A.B., Mooney, D.J., 2001. Polymeric system for dual growth factor delivery. Nat. Biotechnol. 19, 1029-1034.

Roach, P., Farrar, D., Perry, C.C., 2006. Surface tailoring for controlled protein adsorption: effect of topography at the nanometer scale and chemistry. J. Am. Chem. Soc. 128, 3939-3945.

Rodriguez, E., Perez, M., Casanova, P., Martinez, L., 2001. Animal Cell Technology: From Target to Market. Springer, pp. 434-437.

Rumpler, M., Woesz, A., Dunlop, J.W., van Dongen, J.T., Fratzl, P., 2008. The effect of geometry on three-dimensional tissue growth. J. R. Soc. Interface 5, 1173-1180.

Saik, J.E., Gould, D.J., Watkins, E.M., Dickinson, M.E., West, J.L., 2011. Covalently immobilized platelet-derived growth factor-BB promotes angiogenesis in biomimetic poly(ethylene glycol) hydrogels. Acta Biomater. 7, 133-143.

Salehinejad, P., Alitheen, N.B., Mandegary, A., Nematollahi-mahani, S.N., Janzamin, E., 2013. Effect of EGF and FGF on the expansion properties of human umbilical cord mesenchymal cells. In Vitro Cell. Dev. Biol. Anim. 49, 515-523.

Sandino, C., Planell, J.A., Lacroix, D., 2008. A finite element study of mechanical stimuli in scaffolds for bone tissue engineering. J. Biomech. 41, 1005-1014.

Santo, V.E., Duarte, A.R., Popa, E.G., Gomes, M.E., Mano, J.F., Reis, R.L., 2012a. Enhancement of osteogenic differentiation of human adipose derived stem cells by the controlled release of platelet lysates from hybrid scaffolds produced by supercritical fluid foaming. J. Control. Release 162, 19-27.

Santo, V.E., Gomes, M.E., Mano, J.F., Reis, R.L., 2012b. Chitosan-chondroitin sulphate nanoparticles for controlled delivery of platelet lysates in bone regenerative medicine. J. Tissue Eng. Regen. Med. 6 (Suppl. 3), s47-s59.

Santo, V.E., Gomes, M.E., Mano, J.F., Reis, R.L., 2012c. From nano- to macro-scale: nanotechnology approaches for spatially controlled delivery of bioactive factors for bone and cartilage engineering. Nanomedicine (London) 7, 1045-1066.

Santo, V.E., Gomes, M.E., Mano, J.F., Reis, R.L., 2013. Controlled release strategies for bone, cartilage, and osteochondral engineering-part I: recapitulation of native tissue healing and variables for the design of delivery systems. Tissue Eng. B Rev. 19, 308-326.

Santos, M.I., Tuzlakoglu, K., Fuchs, S., Gomes, M.E., Peters, K., Unger, R.E., Piskin, E., Reis, R.L., Kirkpatrick, C.J. 2008. Endothelial cell colonization and angiogenic potential of combined nano- and micro-fibrous scaffolds for bone tissue engineering. Biomaterials 29, 4306-4313.

Santos, J.R., Alves, N.M., Mano, J.F., 2010. New thermo-responsive hydrogels based on poly(N-isopropylacrylamide)/hyaluronic acid semi-interpenetrated polymer networks: swelling properties and drug release studies. J. Bioact. Compat. Polym. 25, 169-184.

Sayyar, B., Dodd, M., Marquez-Curtis, L., Janowska-Wieczorek, A., Hortelano, G., 2014. Fibronectin-alginate microcapsules improve cell viability and protein secretion of encapsulated factor IX-engineered human mesenchymal stromal cells. Artif. Cells Nanomed. Biotechnol. 1-10.

Schneider, P.R., Buhrmann, C., Mobasheri, A., Matis, U., Shakibaei, M., 2011. Threedimensional high-density co-culture with primary tenocytes induces tenogenic differentiation in mesenchymal stem cells. J. Orthop. Res. 29, 1351-1360.

Schofield, R., 1977. The relationship between the spleen colony-forming cell and the haemopoietic stem cell. Blood Cells 4, 7-25. 
Schultz, G.S., Wysocki, A., 2009. Interactions between extracellular matrix and growth factors in wound healing. Wound Repair Regen. 17, 153-162.

Schuurman, W., Khristov, V., Pot, M.W., van Weeren, P.R., Dhert, W.J., Malda, J., 2011. Bioprinting of hybrid tissue constructs with tailorable mechanical properties. Biofabrication 3, 021001

Semple, J.W., Italiano Jr., J.E., Freedman, J., 2011. Platelets and the immune continuum. Nat. Rev. Immunol. 11, 264-274.

Sephel, G.C., Woodward, S.C., 2001. Lippincott. Williams \& Wilkins, Baltimore, pp. 84-117.

Shah, N.J., Hyder, M.N., Quadir, M.A., Dorval Courchesne, N.M., Seeherman, H.J., Nevins, M., Spector, M., Hammond, P.T., 2014. Adaptive growth factor delivery from a polyelectrolyte coating promotes synergistic bone tissue repair and reconstruction. Proc. Natl. Acad. Sci. U. S. A. 111, $12847-12852$.

Sher, P., Custódio, C.A., Mano, J., 2010. Layer-by-layer technique for producing porous nanostructured 3D constructs using moldable freeform assembly of spherical templates. Small 6, 2644-2648.

Sher, P., Correia, C.R., Costa, R.R., Mano, J.F., 2015a. Compartmentalized bioencapsulated liquefied 3D macro-construct by perfusion-based layer-by-layer technique. RSC Adv. 5, 2511-2516.

Sher, P., Oliveira, S.M., Borges, J., Mano, J.F., 2015b. Assembly of cell-laden hydrogel fiber into non-liquefied and liquefied 3D spiral constructs by perfusion-based layer-bylayer technique. Biofabrication 7, 011001.

Shi, J., Alves, N.M., Mano, J.F., 2007. Thermally responsive biomineralization on biodegradable substrates. Adv. Funct. Mater. 17, 3312-3318.

Shi, J., Alves, N.M., Mano, J.F., 2008. Chitosan coated alginate beads containing poly(Nisopropylacrylamide) for dual-stimuli-responsive drug release. J. Biomed. Mater. Res. B Appl. Biomater. 84, 595-603.

Silva, N.A., Salgado, A.J., Sousa, R.A., Oliveira, J.T., Pedro, A.J., Leite-Almeida, H., Cerqueira, R., Almeida, A., Mastronardi, F., Mano, J.F., Sousa, N., Neves, N.M., Reis, R.L., 2009. Development and characterization of a novel hybrid tissue engineering-based scaffold for spinal cord injury repair. Tissue Eng. A 16, 45-54.

Silva, S.S., Mano, J.F., Reis, R.L., 2010. Potential applications of natural origin polymerbased systems in soft tissue regeneration. Crit. Rev. Biotechnol. 30, 200-221.

Silva, J.M., Georgi, N., Costa, R., Sher, P., Reis, R.L., Van Blitterswijk, C.A., Karperien, M. Mano, J.F., 2013a. Nanostructured 3D constructs based on chitosan and chondroitin sulphate multilayers for cartilage tissue engineering. PLoS One 8, e55451.

Silva, S.S., Caridade, S.G., Mano, J.F., Reis, R.L., 2013b. Effect of crosslinking in chitosan/aloe vera-based membranes for biomedical applications. Carbohydr. Polym. 98, 581-588.

Simon Jr., C.G., Lin-Gibson, S., 2011. Combinatorial and high-throughput screening of biomaterials. Adv. Mater. 23, 369-387.

Sin, D., Miao, X.G., Liu, G., Wei, F., Chadwick, G., Yan, C., Friis, T., 2010. Polyurethane (PU) scaffolds prepared by solvent casting/particulate leaching (SCPL) combined with centrifugation. Mater. Sci. Eng. C 30, 78-85.

Singer, N.G., Caplan, A.I., 2011. Mesenchymal stem cells: mechanisms of inflammation. Annu. Rev. Pathol. 6, 457-478

Singhvi, R., Kumar, A., Lopez, G.P., Stephanopoulos, G.N., Wang, D.I., Whitesides, G.M., Ingber, D.E., 1994. Engineering cell shape and function. Science 264, 696-698.

Sipe, J.B., Zhang, J.H., Waits, C., Skikne, B., Garimella, R., Anderson, H.C., 2004. Localization of bone morphogenetic proteins (BMPs)-2,-4, and-6 within megakaryocytes and platelets. Bone 35, 1316-1322.

Sobral, J.M., Caridade, S.G., Sousa, R.A., Mano, J.F., Reis, R.L., 2011. Three-dimensional plotted scaffolds with controlled pore size gradients: effect of scaffold geometry on mechanical performance and cell seeding efficiency. Acta Biomater. 7, 1009-1018.

Song, W.L, Mano, J.F., 2013. Interactions between cells or proteins and surfaces exhibiting extreme wettabilities. Soft Matter 9, 2985-2999.

Song, W.L., Veiga, D.D., Custodio, C.A., Mano, J.F., 2009. Bioinspired degradable substrates with extreme wettability properties. Adv. Mater. $21(1830-+)$.

Souza, G.R., Molina, J.R., Raphael, R.M., Ozawa, M.G., Stark, D.J., Levin, C.S., Bronk, L.F., Ananta, J.S., Mandelin, J., Georgescu, M.M., Bankson, J.A., Gelovani, J.G., Killian, T.C. Arap, W., Pasqualini, R., 2010. Three-dimensional tissue culture based on magnetic cell levitation. Nat. Nanotechnol. 5, 291-296.

Stellos, K., Kopf, S., Paul, A., Marquardt, J.U., Gawaz, M., Huard, J., Langer, H.F., 2010. Platelets in Regeneration.

Stuart, M.A., Huck, W.T., Genzer, J., Muller, M., Ober, C., Stamm, M., Sukhorukov, G.B., Szleifer, I., Tsukruk, V.V., Urban, M., Winnik, F., Zauscher, S., Luzinov, I., Minko, S., 2010. Emerging applications of stimuli-responsive polymer materials. Nat. Mater. 9, 101-113.

Tabata, Y., 2003. Tissue regeneration based on growth factor release. Tissue Eng. 9 (Suppl. 1), $\mathrm{S} 5-\mathrm{S} 15$.

Takeichi, M., 1991. Cadherin cell-adhesion receptors as a morphogenetic regulator. Science 251, 1451-1455.

Tamagawa, H., Takahashi, Y., 2008. Adhesion force behavior between two gels attached with an electrolytic polymer liquid. Mater. Chem. Phys. 107, 164-170.

Tang, Z., Wang, Y. Podsiadlo, P., Kotov, N.A., 2006. Biomedical applications of layer-bylayer assembly: from biomimetics to tissue engineering. Adv. Mater. 18, 3203-3224.

Tang, S., Zhu, J., Xu, Y., Xiang, A.P., Jiang, M.H., Quan, D., 2013. The effects of gradients of nerve growth factor immobilized PCLA scaffolds on neurite outgrowth in vitro and peripheral nerve regeneration in rats. Biomaterials 34, 7086-7096.

Thadavirul, N., Pavasant, P., Supaphol, P., 2014. Development of polycaprolactone porous scaffolds by combining solvent casting, particulate leaching, and polymer leaching techniques for bone tissue engineering. J. Biomed. Mater. Res. A 102, 3379-3392.

Truong, Y.B., Glattauer, V., Briggs, K.L., Zappe, S., Ramshaw, J.A., 2012. Collagen-based layer-by-layer coating on electrospun polymer scaffolds. Biomaterials 33, 9198-9204.

Tsang, V.L., Chen, A.A., Cho, L.M., Jadin, K.D., Sah, R.L., DeLong, S., West, J.L., Bhatia, S.N., 2007. Fabrication of 3D hepatic tissues by additive photopatterning of cellular hydrogels. FASEB J. 21, 790-801.

Tuzlakoglu, K., Bolgen, N., Salgado, A.J., Gomes, M.E., Piskin, E., Reis, R.L., 2005. Nano- and micro-fiber combined scaffolds: a new architecture for bone tissue engineering. J. Mater. Sci. Mater. Med. 16, 1099-1104.
Ullrich, A., Schlessinger, J., 1990. Signal transduction by receptors with tyrosine kinase activity. Cell 61, 203-212.

Utz, E.R., Elster, E.A., Tadaki, D.K., Gage, F., Perdue, P.W., Forsberg, J.A., Stojadinovic, A., Hawksworth, J.S., Brown, T.S., 2010. Metalloproteinase expression is associated with traumatic wound failure. J. Surg. Res. 159, 633-639.

van den Dolder, J., Bancroft, G.N., Sikavitsas, V.I., Spauwen, P.H., Mikos, A.G., Jansen, J.A., 2003. Effect of fibronectin-and collagen I-coated titanium fiber mesh on proliferation and differentiation of osteogenic cells. Tissue Eng. 9, 505-515.

Vieira-de-Abreu, A., Campbell, R.A., Weyrich, A.S., Zimmerman, G.A., 2012. Platelets: Versatile Effector Cells in Hemostasis, Inflammation, and the Immune Continuum.

Walpole, J., Papin, J.A., Peirce, S.M., 2013. Multiscale computational models of complex biological systems. Annu. Rev. Biomed. Eng. 15, 137-154.

Wang, Q., Wang, J., Lu, Q., Detamore, M.S., Berkland, C., 2010. Injectable PLGA based colloidal gels for zero-order dexamethasone release in cranial defects. Biomaterials 31, 4980-4986.

Wang, J., Ye, Y., Tian, H., Yang, S., Jin, X., Tong, W., Zhang, Y., 2011a. In vitro osteogenesis of human adipose-derived stem cells by coculture with human umbilical vein endothelial cells. Biochem. Biophys. Res. Commun. 412, 143-149.

Wang, W., Li, D., Wang, M.C., Li, Y.L, Gao, C.Y., 2011b. A hybrid scaffold of poly(lactide-co-glycolide) sponge filled with fibrin gel for cartilage tissue engineering. Chin. J. Polym. Sci. 29, 233-240.

Wang, Y., Gu, B., Burgess, D.J., 2014. Microspheres prepared with PLGA blends for delivery of dexamethasone for implantable medical devices. Pharm. Res. 31, 373-381.

Weibrich, G., Kleis, W.K., Hafner, G., Hitzler, W.E., 2002. Growth factor levels in plateletrich plasma and correlations with donor age, sex, and platelet count. J. CranioMaxillofac. Surg. 30, 97-102.

Wen-tao, Q., Ying, Z., Juan, M., Xin, G., Yu-bing, X., Wei, W., Xiaojun, M., 2006. Optimization of the cell seeding density and modeling of cell growth and metabolism using the modified Gompertz model for microencapsulated animal cell culture. Biotechnol. Bioeng. 93, 887-895.

Weyrich, A.S., Zimmerman, G.A., 2004. Platelets: signaling cells in the immune continuum. Trends Immunol. 25, 489-495.

Witte, M.B., Barbul, A. 1997. General principles of wound healing. Surg. Clin. N. Am. 77, 509-528.

Woodfield, T.B.F., Van Blitterswijk, C.A., De Wijn, J., Sims, T.J., Hollander, A.P., Riesle, J., 2005. Polymer scaffolds fabricated with pore-size gradients as a model for studying the zonal organization within tissue-engineered cartilage constructs. Tissue Eng. 11, 1297-1311.

Wu, X., Liu, Y., Li, X., Wen, P., Zhang, Y., Long, Y., Wang, X., Guo, Y., Xing, F., Gao, J., 2010 Preparation of aligned porous gelatin scaffolds by unidirectional freeze-drying method. Acta Biomater. 6, 1167-1177.

Xu, F., Finley, T.D., Turkaydin, M., Sung, Y.R., Gurkan, U.A., Yavuz, A.S., Guldiken, R.O., Demirci, U., 2011a. The assembly of cell-encapsulating microscale hydrogels using acoustic waves. Biomaterials 32, 7847-7855.

Xu, F., Wu, C.A., Rengarajan, V., Finley, T.D., Keles, H.O., Sung, Y., Li, B., Gurkan, U.A., Demirci, U., 2011b. Three-dimensional magnetic assembly of microscale hydrogels. Adv. Mater. 23, 4254-4260.

Yan, L Sui, M. Nan, L. Cynthia, K.Y. Jing M., David, H.P. Franklin, RT., 2011. Differences between top-down and bottom-up approaches in mineralizing thick, partiallydemineralized collagen scaffolds. Acta Biomater. 7, 1742-1751.

Yang, S.F., Leong, K.F., Du, Z.H., Chua, C.K., 2002. The design of scaffolds for use in tissue engineering. Part II. Rapid prototyping techniques. Tissue Eng. 8, 1-11.

Yang, J., Yamato, M., Kohno, C., Nishimoto, A., Sekine, H., Fukai, F., Okano, T., 2005. Cell sheet engineering: recreating tissues without biodegradable scaffolds. Biomaterials 26, 6415-6422.

Yang, J., Yamato, M., Shimizu, T., Sekine, H., Ohashi, K., Kanzaki, M., Ohki, T., Nishida, K. Okano, T., 2007. Reconstruction of functional tissues with cell sheet engineering. Biomaterials 28, 5033-5043.

Yang, C., Tibbitt, M.W., Basta, L., Anseth, K.S., 2014. Mechanical memory and dosing influence stem cell fate. Nat. Mater. 13, 645-652.

Yeo, M.G., Kim, G.H., 2011. Preparation and characterization of 3D composite scaffolds based on rapid-prototyped PCL/ $\beta$-TCP struts and electrospun PCL coated with collagen and HA for bone regeneration. Chem. Mater. 24, 903-913.

Yeo, M., Kim, G., 2014. Cell-printed hierarchical scaffolds consisting of micro-sized polycaprolactone ( $\mathrm{PCL}$ ) and electrospun PCL nanofibers/cell-laden alginate struts for tissue regeneration. J. Mater. Chem. B 2, 314-324.

Yim, E.K., Leong, K.W., 2005. Significance of synthetic nanostructures in dictating cellular response. Nanomedicine 1, 10-21.

Yoshimoto, H., Shin, Y.M., Terai, H., Vacanti, J.P., 2003. A biodegradable nanofiber scaffold by electrospinning and its potential for bone tissue engineering. Biomaterials 24, 2077-2082.

Zarbock, A., Polanowska-Grabowska, R.K., Ley, K., 2007. Platelet-neutrophil-interactions: linking hemostasis and inflammation. Blood Rev. 21, 99-111.

Zeltinger, J., Sherwood, J.K., Graham, D.A., Mueller, R., Griffith, L.G., 2001. Effect of pore size and void fraction on cellular adhesion, proliferation, and matrix deposition. Tissue Eng. 7, 557-572.

Zhang, Y.Z., Venugopal, J. Huang Z.M. Lim, C.T. Ramakrishna, S, 2005. Characterization of the surface biocompatibility of the electrospun PCL-collagen nanofibers using fibroblasts. Biomacromolecules 6, 2583-2589.

Zhang, L., Cao, Z., Bai, T., Carr, L., Ella-Menye, J.R., Irvin, C., Ratner, B.D., Jiang, S., 2013. Zwitterionic hydrogels implanted in mice resist the foreign-body reaction. Nat. Biotechnol. 31, 553-556.

Zhang, J., Yin, H.M., Hsiao, B.S., Zhong, G.J., Li, Z.M., 2014. Biodegradable poly(lactic acid)/ hydroxyl apatite 3D porous scaffolds using high-pressure molding and salt leaching. J. Mater. Sci. 49, 1648-1658.

Zhou, C., Ye, X., Fan, Y., Ma, L., Tan, Y., Qing, F., Zhang, X., 2014. Biomimetic fabrication of a three-level hierarchical calcium phosphate/collagen/hydroxyapatite scaffold for bone tissue engineering. Biofabrication 6, 035013.

Zong, X., Bien, H., Chung, C.Y., Yin, L., Fang, D., Hsiao, B.S., Chu, B., Entcheva, E., 2005 Electrospun fine-textured scaffolds for heart tissue constructs. Biomaterials 26 , 5330-5338. 